\title{
Nano- and Micro-mechanical Properties of Ultrafine-Grained Materials Processed by Severe Plastic Deformation Techniques
}

\author{
Megumi Kawasaki a,b,*, Byungmin Ahn c, Praveen Kumar d, Jae-il Jang a, \\ Terence G. Langdon b,e \\ ${ }^{a}$ Division of Materials Science \& Engineering and the Research Institute of Industrial \\ Science, Hanyang University, Seoul 133-791, South Korea \\ ${ }^{\mathrm{b}}$ Departments of Aerospace \& Mechanical Engineering and Materials Science, \\ University of Southern California, Los Angeles, CA 90089-1453, U.S.A. \\ ${ }^{\mathrm{c}}$ Departments of Materials Science and Engineering and Energy Systems Research, \\ Ajou University, Suwon 443-749, South Korea \\ ${ }^{\mathrm{d}}$ Department of Materials Engineering, Indian Institute of Science, Bangalore 560012, India \\ ${ }^{\mathrm{e}}$ Materials Research Group, Faculty of Engineering and the Environment, \\ University of Southampton, Southampton SO17 1BJ, U.K.
}

\begin{abstract}
The processing of metals through the application of severe plastic deformation (SPD) techniques provides the potential for achieving exceptional grain refinement leading to ultrafine-grained (UFG) materials in bulk solids. These materials generally exhibit high strength but very limited ductility at room temperature (RT) leading to the so-called paradox of strength and ductility. The recent development of the novel technique of nanoindentation provides significant feasibility in evaluating the micro-mechanical behavior of UFG materials since the technique provides information on the detailed changes in several mechanical properties during grain refinement through SPD processing. Accordingly, this review examines the available experimental results showing the enhancement in strength and ductility in terms of the micro-mechanical response at RT in a range of metals and alloys after several different SPD processing procedures. A comprehensive tabulation is also presented listing the available data for the strain rate sensitivity, $m$, in a series of UFG metals processed by SPD.
\end{abstract}

Keywords: high-pressure torsion; nanoindentation; severe plastic deformation; strain rate sensitivity; ultrafine grains

*Corresponding author: Megumi Kawasaki, megumi@ hanyang.ac.kr, +82-2-2220-0404 


\section{Introduction}

It is now well established that the physical properties of bulk polycrystalline materials depend critically on a range of structural parameters including the dislocation density, the size and coherency of precipitates, the presence and nature of impurities and alloying elements as well as additional essential material properties such as the values of the elastic moduli and the stacking fault energy. Nevertheless, the most important structural parameter, and the parameter that plays a major role in determining the strength and plasticity of the material, is the grain size, $d$, within the polycrystalline matrix.

Numerous empirical studies have demonstrated that materials having small grain sizes often achieve superior mechanical properties. For example, the strength at ambient temperatures is dictated through the Hall-Petch relationship [1,2] where the yield strength varies inversely with the grain size raised to a power of one-half so that the strength increases when the grain size is reduced. Moreover, compared with conventional coarse-grained (CG) materials, the ductility may be enhanced with a reduction in grain size. Concurrently, a rise in toughness is often anticipated with reducing grain size and a schematic illustration of the effect of decreasing grain size on several mechanical properties is shown in Fig. 1 [3]. In addition, at elevated temperatures, in the regime where diffusion becomes important, a reduced grain size leads to a potential for achieving superplastic flow and thus a superplastic forming capability [4-7]. Accordingly, metallic materials having small grain sizes are very attractive for various structural and functional applications ranging from automotive, aerospace and space engineering industries to electronics and bio-medical applications $[8,9]$. It is now well accepted that ultrafine-grained (UFG) materials are defined as having submicron grains in the range of $100-1000 \mathrm{~nm}$ or nanocrystalline grains with sizes in the range of $10-100 \mathrm{~nm}[10]$. 
In order to convert a CG metal solid into a material with ultrafine or nanoscale grains, it is necessary to impose an exceptionally high strain on the material so that a high density of dislocations is introduced which leads subsequently to microstructural rearrangement and the forming of an array of grain boundaries. Accordingly, a significant interest has developed in the processing of bulk UFG materials without involving any major changes in the overall dimensions of the work-pieces through the application of severe plastic deformation (SPD) [11]. It should be noted that UFG materials processed through SPD are referred to as interface-controlled materials where the grain boundaries are specially arranged by severe straining leading to superior mechanical and functional properties [12]. Regarding a number of currently available SPD techniques [13], the major SPD processing methods include equalchannel angular pressing (ECAP) [14], high-pressure torsion (HPT) [15] and accumulative roll-bonding (ARB) [16,17].

A critical issue arising during developments in the processing of these UFG materials is that there is often only a limited ductility when the size of the grains is reduced although a high strength is generally achieved. This is known as the so-called paradox of strength and ductility [18] which is further described by stating the appropriate maxim "Materials may be strong or ductile, but rarely both at once" $[19,20]$.

A visual presentation of the paradox of strength and ductility was demonstrated in a plot of yield strength versus elongation to failure as shown in Fig. 2 [18]. The yield strength of $\mathrm{Cu}$ and $\mathrm{Al}$ monotonically increase with increasing plastic deformation by cold rolling (as shown by the percentages added to the lines for $\mathrm{Al}$ and $\mathrm{Cu}$ ) whereas their ductility decreases significantly so that the values of strength and elongation are always within the shaded region demonstrating conventional behavior following the paradox of strength and ductility. A consistent conclusion was also demonstrated in an earlier report surveying the numerous experimental results on the strength and ductility of various UFG materials after SPD as 
shown in Fig. 3 [21]. Despite the differences in structural states, processing techniques and routes and the levels of grain refinement, the influence of a reduction in grain size on the strength-ductility relationship demonstrates a consistent trend in the paradox of strength and ductility in SPD-processed UFG materials. It should be noted that the blue region in Fig. 3 denotes materials after short post-processing annealing which is often important for improving the ductility. This additional procedure offers the potential of ordering the defect structures within the grain boundaries, thereby producing more equilibrated grain boundaries without incurring any significant grain growth [22].

In recent developments of SPD techniques, however, extraordinary combinations of high strength and excellent ductility were observed in several UFG metals, including Al [2325], $\mathrm{Cu}$ [26], Ni [27], Ti [28] and an Fe-Ni-Al-C alloy [29] after different SPD techniques. Moreover, Fig. 2 includes limited examples of the extraordinary combinations of mechanical properties of nano $\mathrm{Cu}$ and nano $\mathrm{Ti}$ in the upper white region where the pure $\mathrm{Cu}$ was subjected to $\mathrm{ECAP}$ for 16 passes and the pure $\mathrm{Ti}$ was processed by HPT for 5 revolutions and subsequent heating at $250{ }^{\circ} \mathrm{C}$ for $10 \mathrm{~min}$. This excellent combination of high strength and high ductility was suggested as a consequence of the increase in the fraction of high-angle grain boundaries by introducing a high level of straining through SPD which leads to a change in the dominant deformation mechanisms and a consequent increase in the feasibility of grain boundary sliding (GBS) and grain rotation $[18,20]$.

Recent developments in characterization techniques lead to a better understanding of the evolution in the mechanical properties of UFG materials processed by SPD. In particular, the novel technique of nanoindentation has become a common tool for the simultaneous measurement of a number of mechanical properties by using a small microstructural scale [30]. Thus, there have been several studies reporting the use of the nanoindentation technique for investigating the plastic deformation properties of SPD-processed metals [31] while 
numerous studies demonstrated conventional mechanical testing in tension and compression using bulk UFG metals.

Accordingly, the present report was initiated to review the available experimental results to date that provide an enhancement in strength and ductility in terms of the micromechanical behavior at room temperature (RT) in a range of metals and alloys after SPD processing. Specifically, this report has several objectives. First, the following section describes a promising characterization method, the nanoindentation technique, for determining strength and ductility in UFG materials after different SPD techniques. Next, recent nanoindentation examinations on UFG metals are described after several different SPD techniques including ARB, ECAP and HPT processing. Finally, the last section presents an alternative approach to understand the enhanced ductility through grain refinement by tabulating the available data of the strain rate sensitivity, $m$, in a series of UFG metals processed by SPD.

\section{Characterization of strength and ductility}

It is well understood that the lower overall ductility in UFG materials is due to the low rate of strain hardening where the lowered strain hardening rate competes with the increasing strain rate sensitivity in these materials having small grain sizes [12,32]. Under tensile stresses, the accumulated dislocations of the crystalline state cause work hardening and lead to a difficulty in producing plastic deformation. Thus, it is reasonably expected that a faster rate of work hardening with reasonable strain rate sensitivity will lead to dislocation accumulation within the grains and thus to a delay in the occurrence of localized deformation, such as necking, so that the materials are able to exhibit reasonable levels of tensile ductility. Accordingly, precise testing methods for evaluating and quantifying the mechanical properties of strength and ductility are essential requirements for achieving a better understanding of the 
mechanical characteristics of these UFG materials as well as the significance of the SPD techniques.

Plastic properties include both the strength properties and the creep, fatigue and fracture characteristics and these are all structure-sensitive. These mechanical properties in a material determine the response to the application of a stress which is applied in tension, compression or shear and in a uniaxial or a combination mode. For over 100 years, studies of plastic deformation involved using specimens in conventional tensile testing and this has been the main source for information on the mechanical properties of these materials. The values obtained from this testing for stress and strain are considered as the immediate practical values of the mechanical properties of the material.

However, there are several limitations and complications, especially for UFG materials processed by SPD, in using the tensile testing method and interpreting the testing results. The most critical issue relates to the sensitivity and dependency of these properties to the sample geometry [33-36]. In practice, with the current laboratory-scale studies on the SPD techniques, the tensile specimens machined from SPD-processed samples have often failed to meet the geometry defined by the American Society for Testing and Materials (ASTM) standard [37]. Specifically, most specimens have gauge lengths and thicknesses of $\sim 5 \mathrm{~mm}$ and $\sim 1-2 \mathrm{~mm}$, respectively, after ECAP [38] but the lengths and thicknesses of the gauges decrease to $\sim 1.0-2.0 \mathrm{~mm}$ and $<1.0 \mathrm{~mm}$, respectively, for HPT-processed samples with a $10 \mathrm{~mm}$ diameter [39-41]. An example of the typical miniature tensile sample dimension is shown in Fig. 4 for an HPT-processed disk having a $10 \mathrm{~mm}$ diameter where the tensile sample is cut from the off-center position of the HPT disk [39]. As shown in Fig. 4, additional measurements of Vickers microhardness and microstructural analysis by transmission electron microscopy (TEM) are generally conducted separately at the local region. 
An earlier report suggested that the uniform elongation and post-necking elongation increase with decreasing gauge length and increasing specimen thickness [34]. In addition, tensile specimens having very small cross-sections are generally less ductile than larger specimens. Thus, there is a significant effect of the tensile specimen dimension on the measured mechanical properties and, since there is currently no fixed standard for the miniaturized tensile specimens, published results using different miniature tensile sample dimensions are not directly comparable.

Moreover, several recent studies demonstrated that materials processed by SPD techniques include a gradient-type nanostructure according to grain size and composition $[42,43]$. This type of microstructure is well-known in many biological systems [44] but it is demonstrated as a new type of structure in engineering materials leading to a significant potential for exhibiting excellent mechanical properties [45-48]. Thus, for understanding the local mechanical properties with gradations in microstructure, the nanoindentation technique has been indispensable for measuring the local mechanical response using a limited volume of material at arbitrarily selected local points.

In practice, the nanoindentation technique developed over the last decades [49-51] has become especially important for the mechanical characterization of UFG materials after SPD where the properties can be observed on the material surfaces at the submicron scale. The attraction of this technique arises from the limited volumes in the SPD-processed materials which produce a difficulty in measuring the mechanical properties using conventional tensile testing. Moreover, the technique provides the ability to determine several mechanical properties through the procedure with an accurate recording of various parameters including load, depth and time of nanoindentation, and with the measurements providing the mechanical properties including hardness and elastic modulus and the mechanical parameters of the hardening exponents, creep parameters and residual stresses. A recent review of 
nanoindentation describes the role, significance and feasibility of the nanoindentation technique [31]. Moreover, very recent reports describe current advances and capabilities of nanoindentation measurements for studying thermally-activated deformation mechanisms ranging from single crystalline to nanocrystalline metals through strain rate jump testing and long term creep testing [52] and for operating at high temperature in situ in a scanning electron microscope (SEM) [53].

General nanoindentation procedures were reported earlier where a variety of indentation modes were all used to explore the load versus penetration depth diagram acquired during the test [49-51]. Briefly, when a given geometrical indenter impacts the surface of the material with a constant indentation rate, a force, $P$, and displacement, $h$, are recorded as the tip of the indenter penetrates into the surface of the testing material with an arbitrarily selected loading and unloading profile. This operation provides a loaddisplacement $(P-h)$ curve describing the micro-scale response of the tested material. Examples of typical $P$ - $h$ curves obtained during nanoindentation are shown in Fig. 5 for pure $\mathrm{Al}$ and an Al-Zn alloy having different grain sizes [54]. The differences in the global shapes of the $P$ - $h$ curves arise from the difference in the mechanical properties of these materials having different size of grains.

From the $P-h$ curves, the nanoindentation hardness, $H$, may be estimated according to the Oliver-Pharr method [49]:

$$
H=\frac{P_{\max }}{A}
$$

where $P_{\max }$ is the peak indentation load and $A$ is the contact area of the hardness impression. It should be noted that there is an essential difference in the value of $H v$ obtained from the Vickers microhardness technique and $H$ from the nanoindentation measurements $[55,56]$. There are two reasons for this difference. First, the contact area $A$ in eq. (1) is the surface area for conventional Vickers hardness whereas it is the projected area for the 
nanoindentation hardness [54]. Second, there is an indentation size effect which is manifest as an increase in $H$ with decreasing indentation load $P$ (and depth $h$ ) for sharp indentations [57-59]. Besides the fundamental nanoindentation procedure, the indentation time-holding test has gradually taken the place of traditional uniaxial tensile or compressive load-constant testing in order to study the time-dependent plastic deformation of materials, also referred to as creep $[60,61]$.

The strain rate sensitivity, $m$, can be determined using the measured hardness value at a given strain, $\varepsilon$, and absolute temperature, $T$, by the expression $[62,63]$ :

$$
m=\left(\frac{\partial \ln \sigma_{f}}{\partial \ln \dot{\varepsilon}}\right)_{\varepsilon, T}=\left(\frac{\partial \ln (H / C)}{\partial \ln \left(0.01 \dot{\varepsilon}_{i}\right)}\right)_{\varepsilon, T}
$$

where the flow stress, $\sigma_{f}$, is estimated by the Tabor empirical relation of $\sigma_{f} \approx H / C$ where $C$ is a constraint factor of $\sim 3$ for fully plastic deformation [64] and the indentation strain rate, $\dot{\varepsilon}_{i}$, is estimated by $\dot{\varepsilon}_{i}=h^{-1}(d h / d t)$, where there is the empirical relation for the uniaxial strain rate of $\dot{\varepsilon} \approx 0.01 \dot{\varepsilon}_{\mathrm{i}}[65]$.

In addition, through the nanoindentation testing, the mechanism of the rate-dependent plastic deformation may be estimated from the value of the activation volume $V_{p}{ }^{*}$ which is given by $[66,67]$

$$
V_{p}^{*}=\sqrt{3} k T\left(\frac{\partial \ln \dot{\varepsilon}}{\partial \sigma_{f}}\right)=\sqrt{3} k T\left(\frac{\partial \ln \left(0.01 \dot{\varepsilon}_{\mathrm{i}}\right)}{\partial(H / C)}\right)=\frac{C \sqrt{3} k T}{m H}
$$

where $k$ is Boltzmann's constant. In general, the value of $V_{p}{ }^{*}$ varies by orders of magnitude for different rate-controlling processes with values in the range of $\sim 100 \mathbf{b}^{3}$ to $\sim 1000 \mathbf{b}^{3}$ for dislocation glide of f.c.c. metals [68], $\sim 10 \mathbf{b}^{3}$ for GBS [69] and $\sim \mathbf{b}^{3}$ for diffusion through the grain boundary or crystalline lattice $[68,70]$ where $\mathbf{b}$ is the Burgers vector.

It is important to note that there is no single technique describing all mechanical properties of materials and therefore multiple techniques must be utilized to interpret the 
properties in different length scales. In practice, nanoindentation is generally utilized for detecting and understanding the plastic yield on the nanoscale so that the incipient plasticity focuses on the very early stage of deformation where the transition of elastic to plastic deformation occurs [30]. Conversely, the nanoindentation technique is not usable to determine the classical measures of overall ductility such as elongations to failure and uniform elongations recorded during conventional tensile testing. Nevertheless, it has been well demonstrated that the measurements of the rate sensitivity is sufficient to permit a direct prediction of the stability of plastic deformation at elevated temperatures [71,72]. Moreover, the implication of ductility and the strain rate sensitivity was applied to understand the plasticity and ductility of nanostructured metals when tested at room temperature (RT) $[73,74]$. Thus, the nanoindentation technique provides sufficient and valuable information of strength and ductility in UFG materials processed by SPD.

\section{Recent nanoindentation examinations on UFG metals after SPD processing}

There are numerous studies documenting improved mechanical properties including strength and ductility in UFG materials processed through the application of SPD. Based on these data, recent nanoindentation examinations are presented in this section for a series of UFG non-ferrous metals after various SPD techniques including ARB, ECAP and HPT processing.

\subsection{Nanoindentation on UFG Al processed by ECAP and ARB}

There were limited earlier studies using the nanoindentation technique on nanocrystalline materials produced by electrodeposition [75-77]. Nevertheless, the very first examination using nanoindentation on an SPD-processed material was demonstrated on a UFG $\mathrm{Al}(99.5 \%$ pure) processed through ECAP for 12 passes at RT where the grain size was refined to $\sim 800$

$\mathrm{nm}$ [78]. In the examination, a constant strain rate (CSR) indentation method was used by setting a maximum displacement so that the $P$ - $h$ curves shown in Fig. 6 are different from those shown in Fig. 5 where the maximum load, $P_{\max }$, was set under the CSR testing 
conditions. Thus, the effective indentation strain rate, $\dot{\varepsilon}_{i}$, may be defined by comparison with general tensile testing with the indentation depth rate, $\dot{h}$, divided by the indentation depth, $h$. Accordingly, the strain rate sensitivity is then calculated by the change in the measured $H$ values under several different indentation strain rates. It should be noted that the constant indentation strain rate mode considers an effective strain rate which takes an average rate over the whole deformed indentation volume since stress and strain change nonlinearly in the deformed volume and it is not consistent with conventional tensile testing where the strain rate is controlled as a constant.

The representative $P$ - $h$ curves are displayed in Fig. 6 for UFG-Al and CG-Al tested at constant indentation strain rates of $10^{-1}$ and $10^{-3} \mathrm{~s}^{-1}$. It is apparent that the UFG-Al demonstrates an enhanced strain rate dependency by comparison with CG-Al such that the measurements give $m \approx 0.07$ for UFG-Al where this is much higher than $m \approx 0.027$ for CGAl [78]. Thus, the enhanced strain rate sensitivity may provide the dominant contribution for increasing ductility in the UFG-Al.

A further investigation by nanoindentation was reported on a UFG-Al processed by ARB at RT for 8 cycles to impose an effective strain of 6.4 [31,79] where the grain size was reduced to $d \approx 0.32 \mu \mathrm{m}[80]$. The ARB-processed UFG-Al sample was compared to a UFGAl processed by ECAP for 6 passes at RT in order to impose a consistent effective strain of 6.3 [31] where the sample grain size was reduced to $\sim 0.5 \mu \mathrm{m}$ [24]. The nanoindentation testing recorded the hardness values of the UFG-Al samples at a series of constant indentation strain rates. The results were then applied to calculate the strain rate sensitivities as shown in eq. (2) and a summary is given in Fig. 7 for the UFG-Al after ARB and ECAP [31]. It is seen the values of strain rate sensitivity was very similar as 0.068 and 0.069 for the UFG-Al samples after ECAP and ARB. 
Nevertheless, the pile-up behavior of these two UFG-Al are very different as shown in Fig. 8 where the SEM images are taken at the nanoindentation indents on the sample after (a) ARB and (b) ECAP [31]. It was apparent in the ARB sample that pile-up and lift-up behavior were observed only at the edges of the indent parallel to the layered structure with the elongated grains after ARB which is vertical in Fig. 8(a) whereas pile-up behavior was observed homogeneously around the indent due to the equiaxed grains after ECAP as shown in Fig. 8(b). Because of the significant difference in the morphology around the indents but with similar $m$ values, besides the occurrence of GBS a mechanism of thermally-activated annihilation of dislocations at grain boundaries was activated for the strain rate sensitive behavior of the UFG-Al after ARB and ECAP [31].

It should be noted that there are only limited reports to date on UFG pure metals processed by ECAP and examined by nanoindentation [81-83] and this is attributed to the relatively larger processed sample dimensions leading to a relative ease in using conventional tensile testing for mechanical characterization.

\subsection{Nanoindentation on UFG metals processed through HPT}

Among the reported SPD techniques, one of the most attractive methods refers to the processing by HPT where this type of processing leads to exceptional grain refinement that is not generally achieved using other procedures [84]. Excellent grain refinement through the HPT technique has been reported in a range of metals in the last decade and it has become apparent that HPT processing is attracting very high attention in the materials science community. Accordingly, four recent reports of nanoindentation measurements are summarized for a series of metals and alloys after processing by HPT.

\subsubsection{ZK60 magnesium alloy}

Processing by HPT at RT was conducted on an extruded ZK60 magnesium alloy consisting of a bi-modal grain distribution with a fraction of $>50 \%$ of coarse grains having a size of $\sim 25$ 
$\mu \mathrm{m}$ surrounded by several finer grains of $\sim 4-5 \mu \mathrm{m}$ [85]. Processing through 2 turns under a compressive pressure of $6.0 \mathrm{GPa}$ at $1 \mathrm{rpm}$ led to a bi-modal microstructure with coarse grains with a size of $\sim 20 \mu \mathrm{m}$ and fine grains having an average size of $\sim 1.0-1.5 \mu \mathrm{m}$ existing with a high area fraction of $\sim 75 \%$. This unique microstructural evolution in magnesium alloys is explained by the necklace-like dynamic recrystallization (DRX) where the concentration of deformation occurs across the new fine grains [86].

The nanoindentation hardness at four different indentation strain rates of $0.0125-0.1 \mathrm{~s}^{-1}$ was examined at the edge of each disk and the results are displayed with increasing numbers of HPT turns, $N$, in Fig. 9 [85]. The recalculated $H v$ values from Vickers microhardness measurements, which are comparable to $H$, are included in the plot for comparison purposes. A direct proof of an indentation size effect can be seen in the difference in the datum points between the nanoindentation hardness and Vickers microhardness. Nevertheless, both $H$ and $H v$ show a consistent trend of hardness which increases rapidly in the early stages of HPT and thereafter saturates towards maximum values.

In this study, two different nanoindentation tests were conducted on the as-extruded sample without HPT and on the disk edges of the ZK60 alloy after HPT through 2 turns at four different indentation strain rates from 0.0125 to $0.1 \mathrm{~s}^{-1}$ using a CSR testing mode and strain-rate jump (SRJ) testing mode [85]. These two tests were performed with a three-sided pyramidal Berkovich indenter in order to estimate $m$ following eq. (2). The estimated $m$ values were plotted with increasing numbers of HPT turns as shown in Fig. 10 [85]. It should be noted that the essential merit of the SRJ test is that the estimation is conducted from a single indentation whereas multiple indentations are required in the CSR tests.

Negligible differences are observed in the $m$ values for these two procedures, such as 0.048 from SRJ and $\sim 0.043$ from CSR after HPT for 2 turns. The overall trend with increasing $N$ is consistent for these two testing modes through the nanoindentation analysis. 
Thus, the $m$ value of $\sim 0.035-0.040$ in the as-extruded condition prior to HPT was enhanced significantly to $m \approx 0.043-0.047$ through $1 / 2$ turn and thereafter the values re main reasonably constant up to 2 turns by HPT. This result is in reasonable agreement with a recent report on pure $\mathrm{Mg}$ after extrusion showing $m=0.03$ which was also measured by the CSR method through nanoindentation analysis [87].

\subsection{2. $\mathrm{Zn}-22 \%$ Al eutectoid alloy}

Examinations were conducted using a commercial $\mathrm{Zn}-22 \%$ Al eutectoid alloy consisting of a binary microstructure with an Al-rich $\alpha$ phase and a $\mathrm{Zn}$-rich $\beta$ phase. Several earlier reports demonstrated the capability of attaining excellent superplastic properties with a low workhardening rate at RT [88-90] so that the alloy is applied for tuned mass dampers to reduce seismic vibrations in building structures [91,92]. The processing by HPT was conducted at RT under a compressive pressure of $6.0 \mathrm{GPa}$ for total numbers of $N=1,2$ and 4 turns at 1 rpm [93]. The initial material contained both essentially equiaxed grains with an average size of $\sim 1.4 \mu \mathrm{m}$ and a lamellar structure with thicknesses of $\sim 100 \mathrm{~nm}$. After HPT processing, the disk edges of the material achieved significant grain refinement to $\sim 400 \mathrm{~nm}$ and $\sim 350 \mathrm{~nm}$ through HPT after 2 and 4 turns, respectively.

An analysis by nanoindentation was performed at the disk edges of the HPTprocessed $\mathrm{Zn}-\mathrm{Al}$ alloy. Representative $P$ - $h$ curves are given in Fig. 11 [66] where the main plot shows samples for the as-annealed condition prior to HPT and $N=4$ turns tested at four different $\dot{\varepsilon}_{i}$ and the inset shows all four samples tested at $\dot{\varepsilon}_{i}=0.025 \mathrm{~s}^{-1}$. Two important tendencies are apparent in the $\mathrm{Zn}-\mathrm{Al}$ alloy. First, at any given indentation strain rate, the displacement at the peak load increases after HPT and with increasing $N$. Second, there is a significant rate-dependency on the displacement at the peak load and it is more significant after HPT so that the strain rate sensitivity calculated using eq. (2) is $m>0.026$ in the as- 
processed $\mathrm{Zn}$-Al samples by HPT up to 4 turns and thus is much higher than the as-annealed sample showing $m=0.125$.

Images of the in-situ nanoindentation are shown in Fig. 12(a) for the as-annealed sample without HPT where the shear-off behavior by GBS is apparent in the pile-up region due to the large grain size [66]. The shear-off behavior of UFG metals is evidence for GBS and the unit of shear-off is similar to the grain size $[79,94,95]$. The ex-situ nanoindentation images taken under $P_{\max }=20 \mathrm{mN}$ at $\dot{\varepsilon}_{i}=0.025 \mathrm{~s}^{-1}$ are shown in Fig. 12(b)-(e) for the sample before HPT and the samples after HPT for $N=1,2$ and 4 turns, respectively, where there is clear shear-off phenomena for all samples [66]. The increase in indentation size with increasing HPT turns confirms the decrease in hardness with increasing $N$ and the very clear shear-off behavior is observed especially in the HPT-processed disks up to 4 turns, thereby providing direct proof of active GBS in the UFG Zn-22\% Al alloy processed by HPT. Thus, the reports on the ZK60 and Zn-Al alloys suggest the recognition of a consistent trend of enhanced micro-mechanical plastic behavior in the UFG metals after HPT.

It should be noted that the ZK60 alloy as demonstrated earlier exhibits a hardness behavior involving strain hardening without any apparent dynamic recovery [96] whereas, as documented in a recent report [97], most commercial purity metals and alloys exhibit two types of softening behavior. Specifically, the softening behavior by high-purity metals shows strain hardening in the very early stage of deformation followed by softening due to the microstructural recovery. Another softening behavior is for metals and alloys having low melting temperatures where these materials show strain softening with weakening due to a significant reduction in the hard precipitates under severe straining by HPT [98] and a representative metal for this behavior is the $\mathrm{Zn}-22 \% \mathrm{Al}$ eutectoid alloy [99] and the $\mathrm{Pb}-62 \%$ Sn eutectic alloy [100]. Thus, using nanoindentation analysis, a very recent report examined 
the consistent behavior of softening with weakening in a $\mathrm{Pb}-62 \% \mathrm{Sn}$ alloy after HPT for 1 turn at 3.0 GPa [56].

\subsubsection{High entropy alloy}

A high entropy alloy (HEA) system having a composition of $\mathrm{Co}_{20} \mathrm{Cr}_{20} \mathrm{Fe}_{20} \mathrm{Mn}_{20} \mathrm{Ni}_{20}$ (in at.\%) was prepared by casting. Regardless of the composition, the as-cast HEA has an f.c.c. single phase with an average grain size of $\sim 40 \mu \mathrm{m}$ [67]. Accordingly, the HEA was processed by HPT at RT under 6.0 GPa for totals of $1 / 4,1 / 2,1$ and 2 turns $[61,67]$.

The microstructure after HPT was observed by TEM and the micrographs with SAD patterns are shown in Fig. 13(a) and (b) for the disk edges of the HEA after 1/4 and 2 turns, respectively [61,67]. Direct measurements from the micrographs showed the alloy has a UFG microstructure with average grain sizes of $\sim 60$ and $\sim 40 \mathrm{~nm}$ at the disk edges after HPT for $1 / 4$ and 2 turns, respectively. The SAD patterns demonstrate clear ring patterns and indicate the successful achievement of nanoscale grains without preferred crystallographic orientation for both samples. Thus, a nanocrystalline structure was developed in the HEA in the very early stages of HPT processing whereas HEA is known to have a stable microstructure during plasticity attributed to the requirement of a high activation energy leading to sluggish diffusion. It should be noted that there was no evidence of a phase transformation during the processing.

An examination by nanoindentation was conducted on the HEA before and after HPT up to 2 turns at indentation strain rates from 0.0125 to $0.1 \mathrm{~s}^{-1}$. The main plot in Fig. 14 provides representative $P$ - $h$ curves for the different indentation strain rates for the as-cast and the sample after HPT for 2 turns [67]. The arrows in the main plot demonstrate the effect of increasing indentation strain rate. The inset provides representative $P$ - $h$ curves taken at a strain rate of $0.0125 \mathrm{~s}^{-1}$ for the as-cast specimen and the disk processed by HPT for up to 2 turns. 
There are two important conclusions from Fig. 14. First, it is apparent from the inset that the HPT-processed nanostructured HEA shows a much shorter displacement at the fixed peak load than the as-cast sample thereby indicating the significantly improved hardness in the HEA by HPT processing. Within the HPT samples, there are very limited displacements at the peak load towards the left leading to higher hardness, thereby demonstrating the achievement of saturated hardness and thus a nano-scale microstructure in the very early stage of HPT through 1/4 turn. Second, it is evident for both the as-cast and processed HEA samples that the maximum displacement decreases as the indentation strain rate increases whereas the rate dependency becomes relatively small after deformation through HPT.

The value of $m$ was estimated for the HEA by plotting $H / 3$ versus strain rate for each sample condition as shown in the inset of Fig. 15 and the evolution in the value of $m$ with increasing numbers of HPT turns is shown in the main plot of Fig. 15 [67]. The results demonstrate that, although the values of $m$ are not improved by HPT and this is different from the ZK60 and $\mathrm{Zn}-22 \% \mathrm{Al}$ alloys described earlier, the HPT processing provides an excellent potential for achieving superior strength while maintaining excellent plasticity at RT in the nanostructured HEA. There is very limited research available to date on HEA processed by HPT [101,102] and additional studies are indispensable in order to achieve a better understanding of the significant change towards the nano-scale microstructure through HPT processing at ambient temperature.

\subsubsection{An intermetallic-based metal matrix nanocomposite}

A very recent study demonstrated the formation of a new Al-Mg alloy system from separate disks of an Al-1050 aluminum alloy and the ZK60 alloy through diffusion bonding by means of conventional HPT at RT under a compressive pressure of $6.0 \mathrm{GPa}[42,103,104]$. After 5 turns by HPT, a detailed microstructural analysis was conducted at the disk edge using TEM and a representative photo is shown in Fig. 16 where the Al matrix phase consists of a 
layered structure having thicknesses of $\sim 90-120 \mathrm{~nm}$ and the average grain size, $d$, in the $\mathrm{Al}$ matrix phase was $\sim 190 \mathrm{~nm}[42,103,104]$. There was a single visible Mg phase in Fig. 16 and it had a homogeneous bonding interface with the Al matrix without any visible voids. Moreover, within the Al matrix, several heterogeneously distributed thin layers were observed with an average thickness of $\sim 20 \mathrm{~nm}$ as indicated by the white arrows.

These thin layers were examined closely by elemental mapping and quantitative chemical analysis by point scanning and the detailed analysis revealed no formation of a supersaturated Al solid solution in the matrix of the Al-Mg disk at the edge after 5 HPT turns. The analysis showed the thin layers in Fig. 16 are composed of an intermetallic compound of $\beta-\mathrm{Al}_{3} \mathrm{Mg}_{2}$ which has a low density of $\sim 2.25 \mathrm{~g} / \mathrm{cm}^{3}$ [42,103]. Since the thin layers existed randomly in the Al matrix, the HPT processing synthesized a metal matrix nanocomposite (MMNC) in the formed Al-Mg system at the disk edge after 5 turns. It is anticipated that $\beta$ $\mathrm{Al}_{3} \mathrm{Mg}_{2}$ provides an excellent potential for reinforcing the $\mathrm{Al}$ MMNC by improving the hardness and strength. Accordingly, the Vickers microhardness analysis showed a maximum hardness of $H v \approx 130$ at the disk edge where the MMNC was observed after HPT for 5 turns. This high hardness is significantly higher than $\sim 65$ for the Al-1050 alloy [105] and $\sim 110$ for the ZK60 alloy [96] after HPT for 5 turns and this is due in part to the presence of the intermetallic nanolayers of $\beta-\mathrm{Al}_{3} \mathrm{Mg}_{2}$ in the $\mathrm{Al}$ matrix.

The micro-mechanical response was examined for the MMNC at the disk edge in the Al-Mg system after HPT for 5 turns using a nanoindentation facility [104]. More than 15 indentations were conducted at each specific phase at the measured locations to provide statistically valid data. All measurements were conducted under a predetermined maximum peak load of $P_{\max }=50 \mathrm{mN}$ at four constant indentation strain rates from 0.0125 to $0.1 \mathrm{~s}^{-1}$.

Representative $P$ - $h$ curves are shown in Fig. 17 for the Al-Mg disk edge measured at the slowest indentation strain rate [104]. It is apparent from Fig. 17 that there is a wide 
deviation in plastic behavior for all 15 separate measurements and thus in the plastic instability at the disk edge of the MMNC. It should be noted that the plastic behavior shows smaller displacements for all measurements than the separate $\mathrm{Al}$ and $\mathrm{Mg}$ phases without formation of MMNC after HPT for 5 turns tested at the same indentation rate [104]. Moreover, this plastic instability was observed at all indentation rates although the slower strain rate shows a lower tendency. The constantly small displacements in the Al-Mg system cannot be explained by the simple mixture of $\mathrm{Al}$ and $\mathrm{Mg}$ phases but instead the variation in the plastic behavior is due to the existence of $\beta-\mathrm{Al}_{3} \mathrm{Mg}_{2}$ as nanolayers at the peripheral region of the $\mathrm{Al}-\mathrm{Mg}$ disk after 5 turns.

Subsequently, the strain rate sensitivity, $m$, was determined as explained in eq. (2) and shown in Fig. 18 for the Al-Mg phase at the edge of the disk after HPT for 5 turns [104]. It should be noted that the error bar on each datum point represents the standard deviation of the numbers of nanoindentation measurements. The value of $m<0.01$ was calculated at the disk edge forming the MMNC. With wider error bars due to the plastic instability especially with increasing indentation strain rates, the estimations imply the possibility of a much smaller strain rate sensitivity in the Al MMNC. Thus, the decreased strain rate sensitivity in the MMNC processed from separate $\mathrm{Al}$ and $\mathrm{Mg}$ disks is much smaller than the $m$ values of $\sim 0.07$ for the commercial purity $\mathrm{Al}$ after $\mathrm{ARB}$ and ECAP as shown in Fig. 7 and $m \approx 0.043$ 0.048 for the ZK60 alloy after HPT through 2 turns as shown in Fig. 10.

There are several reports showing a negative strain rate sensitivity in UFG and nanostructured metals including Ti after ECAP followed by cold rolling [106] and Al alloys produced through cryomilling [107,108]. The behavior involves a strain-rate dependent instability of plasticity which is attributed to the occurrence of dynamic strain aging (DSA) leading to the local formation of solute clusters on forest dislocations resulting in a strengthening of dislocation junctions [109]. In addition, there is a limited report of a 
negative strain rate sensitivity for an MMNC of a powder consolidated aluminum 6092/B 4 C when tested at strain rates of $<1.0 \mathrm{~s}^{-1}$ [110]. The latter report suggested the occurrence of DSA due to the presence of the fast diffusion of solute atoms interacting with mobile dislocations. Thus, at the Al MMNC in the Al-Mg system after HPT, decreasing plasticity demonstrated by the reduced strain rate sensitivity is feasible because of the interaction of a significant number of dislocations introduced during HPT with the Mg solutes having very rapid diffusivity within the $\mathrm{Al}$ matrix [42,113]. A recent review describes the acceptance of the fast atomic mobility in UFG metals processed by SPD by recognizing the significant increase in the vacancy concentration during SPD processing [111].

\section{The strain rate sensitivity in UFG metals processed by SPD}

As noted earlier, an undesirable reduction in ductility occurs in bulk materials having UFG microstructure whereas a significant increase in hardness and strength is achieved by grain refinement through SPD. In addition to grain refinement, it is also well defined that UFG materials processed by SPD may receive higher strength by introducing nano-particles, nanotwins and non-equilibrium grain boundaries [112]. Specifically, the low ductility in the UFG materials is attributed to an interrelationship between the two factors of strain hardening capability and strain rate sensitivity [12]. There is generally an increase in strain rate sensitivity which is attributed to higher activity of GBS when the grain size is reduced whereas there is a large decrease in strain hardening by grain refinement in bulk materials.

Nevertheless, as was evident in the improved plasticity in the ZK60, Zn-Al and HEA alloys through the nanoindentation analysis in the earlier section, the enhancement in ductility of UFG metals at RT is anticipated by the sustained plasticity by activating GBS, and thus to an increase in the $m$ value with increasing amount of straining by SPD. Several experimental results are now available for the improved $m$ values in various UFG metals processed from bulk metals by different SPD techniques measured using various testing 
methods and modes. A comprehensive summary is given in Table 1. In this Table, the SPD processing conditions are listed in column 2, the grain sizes achieved after the SPD processing are given in column 3, the columns 4-6 give the testing methods, the measured $m$ values and the applied strain rate ranges of the measurements, respectively, and finally the reference for each report is listed in the last column.

The results documented in Table 1 show that UFG microstructure was achieved successfully in many different metals and alloys after separate SPD techniques where the listed samples include pure $\mathrm{Al}$ and $\mathrm{Al}$ alloys [23,24,31,78-80,83,94,113-127], pure $\mathrm{Cu}$ and $\mathrm{Cu}$ alloys [18,38,62,81,128-137], pure Cr [138], pure Fe [23,62,139], Mg alloys [85,140], pure Nb [82], Pure Ni, [128,141], pure Ta [62,142], pure Ti [28,143], pure W [144-146], Pb-62\% Sn alloy [56], Zn-Al alloys [66,89,147-150], HEA [67] and MMNC [104]. It is apparent that a regular tensile testing method is applied for measuring the $m$ values in most materials. Nevertheless, several recent studies use nanoindentation analysis and the $m$ values measured by different measurement methods show reasonable consistency, as seen in the AA1050A aluminum alloy and pure $\mathrm{Cu}$ in Table 1 . However, the consistency in the $m$ values measured by tensile testing and nanoindentation may be lost depending on the anisotropy of the testing material after SPD [31].

It is recognized that many studies of UFG materials after SPD in Table 1 use simple metals and alloys having a face centered cubic (f.c.c.) structure and it is reasonable to evaluate the improved $m$ value as a function of grain size for UFG $\mathrm{Al}$ and UFG $\mathrm{Cu}$ processed by various SPD techniques as shown in Fig. 19(a) and (b), respectively. The trend of change in the $m$ value with reduction in grain size is denoted by the grey arrow in each plot.

It is apparent in Fig. 19 that there is a trend of enhanced strain rate sensitivity in both UFG-Al and UFG-Cu with reduction in grain size through SPD. This consistent trend was shown earlier for UFG and nanocrystalline f.c.c. metals including $\mathrm{Al}, \mathrm{Cu}$ and $\mathrm{Ni}$ prepared 
mostly by a bottom-up method [151] where the bottom-up strategy involves powder metallurgy, inert gas consolidation or electrodeposition [152]. It should be mentioned that, as seen in Table 1, there is at present less information for UFG metals having the body-centered cubic (b.c.c.) and hexagonal close-packed (h.c.p.) structures processed by SPD. Nevertheless, grain refinement through the application of SPD is an excellent strategy for improving the overall ductility in UFG f.c.c. metals by enhancing GBS which compensates for the reduction in strain hardening.

\section{Summary and conclusions}

(1) This report reviews of the experimental results available to date that demonstrate an enhancement in strength and ductility in terms of the micro-mechanical behavior, especially analyzed through the nanoindentation technique, at room temperature in a range of UFG metals and alloys after SPD processing.

(2) The nanoindentation technique provides a wide range of information including mechanical properties and the local microstructure. In addition to conventional tensile testing, this technique is promising for UFG materials after SPD where the materials may have smaller overall dimensions and include gradient-type microstructures.

(3) The available data on UFG materials processed by SPD demonstrate a consistent trend of increasing strain rate sensitivity with reducing grain size which is attributed to the increasing amount of straining during SPD processing. The trend is depicted for UFG $\mathrm{Al}$ and UFG $\mathrm{Cu}$ samples after different SPD techniques. Thus, grain refinement through SPD provides an excellent strategy for improving tensile ductility as well as high strength in UFG metals by compensating the reduction in strain hardening. 


\section{Acknowledgements}

This work was supported by the NRF Korea funded by MoE under Grant No. NRF2014R1A1A2057697 and NRF-2016R1A6A1A03013422, and by MSIP under Grant No. NRF-2016K1A4A3914691 (MK); the NRF Korea funded by MSIP under Grant No. NRF2015R1A2A2A01002387 (BA); Aeronautics Research and Development Board (ARDB) under Grant No. ARDB0242 (PK); the NRF Korea funded by MSIP under Grant No. NRF2013R1A1A2A10058551 and NRF-2015R1 A5A1037627 (JIJ); and the European Research Council under ERC Grant Agreement No. 267464-SPDMETALS (TGL). 


\section{References}

[1] E.O. Hall, Proc. Phys. Soc. London, Sec. B. 1951, 64, 747.

[2] N.J. Petch, J. Iron. Steel. Inst. 1953, 174, 25.

[3] E. Ma, Scripta Mater. 2003, 49, 663.

[4] M. Kawasaki, T.G. Langdon, J. Mater. Sci. 2008, 43, 7360.

[5] T.G. Langdon, J. Mater. Sci. 2009, 44, 5998.

[6] M. Kawasaki, T.G. Langdon, J. Mater. Sci. 2014, 49, 6487.

[7] M. Kawasaki, T.G. Langdon, J. Mater. Sci. 2016, 51, 19.

[8] T.C Lowe, JOM 2006, 58(4), 28.

[9] R.Z. Valiev, I. Sabirov, A.P. Zhilyaev, T.G. Langdon, JOM 2012, 64, 1134.

[10] R.Z. Valiev, Y. Estrin, Z. Horita, T.G. Langdon, M.J. Zehetbauer, Y.T. Zhu, JOM 2006, 58(4), 33.

[11] R.Z. Valiev, A.P. Zhilyaev, T.G. Langdon, Bulk Nanostructured Materials: Fundamentals and Applications, Wiley-TMS, Hoboken, New Jersey, USA 2014

[12] R.Z. Valiev, Y. Estrin, Z. Horita, T.G. Langdon, M.J. Zehetbauer, Y.T. Zhu, Mater. Res. Lett. 2016, 4, 1.

[13] Y. Estrin, A. Vinogradov, Acta Mater. 2013, 61, 782.

[14] R.Z. Valiev, T.G. Langdon, Prog. Mater. Sci. 2006, 51, 881.

[15] A.P. Zhilyaev, T.G Langdon, Prog. Mater. Sci. 2008, 53, 893.

[16] Y. Saito, N. Tsuji, H. Utsunomiya, T. Sakai, R.G. Hong, Scripta Mater. 1998, 39, 1221.

[17] Y. Saito, H. Utsunomiya, N. Tsuji, T. Sakai, Acta Mater. 1999, 47, 579.

[18] R.Z. Valiev, I.V. Alexandrov, Y.T. Zhu, T.C. Lowe, J. Mater. Res. 2002, 17, 5.

[19] R. Valiev, Nature 2002, 419, 887.

[20] R. Valiev, Nat. Mater. 2004, 3, 511.

[21] A. Vinogradov, Adv. Eng. Mater. 2005, 17, 1710.

[22] O. Andreau, J. Gubicza, N.X. Zhang, Y. Huang, P. Jenei, T.G. Langdon, Mater. Sci. Eng. A 2014, 615, 231. 
[23] H.W. Höppel, J. May, P. Eisenlohr, M. Göken, Z. Metallkd. 2005, 96, 566.

[24] J. May, H.W. Höppel, M. Göken, Scripta Mater. 2005, 53, 189.

[25] T. Mungole, P. Kumar, M. Kawasaki, T.G. Langdon, J. Mater. Res. 2014, 29, 2534.

[26] F. Dalla Torre, R. Lapovok, J. Sandlin, P.F. Thomson, C.H.J. Davies, E.V. Pereloma, Acta Mater. 2004, 52, 4819.

[27] N. Krasilnikov, W. Lojkowski, Z. Pakiela, R. Valiev, Mater. Sci. Eng. A 2005, 397, 330.

[28] R.Z. Valiev, A.V. Sergueeva, A.K. Mukherjee, Scripta Mater. 2003, 49, 669.

[29] K. Edalati, T. Furuta, T. Daio, S. Kuramoto, Z. Horita, Mater. Res. Lett. 2015, 3, 197.

[30] C.A. Schuh, Mater. Today 2006, 9, 32.

[31] A. Böhner, V. Maier, K. Durst, H.W. Höppel. M. Göken, Adv. Eng. Mater. 2011, 13, 251.

[32] Y.T. Zhu, X. Liao, Nat. Mater. 2004, 3, 351.

[33] Y.H. Zhao, Y.Z. Guo, Q. Wei, A.M. Dangelewicz, C. Xu, Y.T. Zhu, T.G. Langdon, Y.Z. Zhou, E.J. Lavernia, Scripta Mater. 2008, 59, 627.

[34] Y.H. Zhao, Y.Z. Guo, Q. Wei, T.D. Topping, A.M. Dangelewicz, Y.T. Zhu, T.G. Langdon, E.J. Lavernia, Mater. Sci. Eng. A 2009, 525, 68.

[35] A.V. Sergueeva, J. Zhou, B.E. Meacham, D.J. Branagan, Mater. Sci. Eng. A 2009, 526, 79 .

[36] L. Yang, L. Lu, Scripta Mater. 2013, 69. 242.

[37] ASTM <http://www.astm.org $>$

[38] Y.M. Wang, E. Ma, Acta Mater. 2004, 52, 1699.

[39] G. Sakai, Z. Horita, T.G. Langdon, Mater. Sci. Eng. A 2005, 393, 344.

[40] Y.Z. Tian, S.D. Wu, Z.F. Zhang, R.B. Figueiredo, N. Gao, T.G. Langdon, Acta Mater. 2011, 59, 2783.

[41] A. Alhamidi, Z. Horita, Mater. Sci. Eng. A 2015, 622, 139.

[42] B. Ahn, A.P. Zhilyaev, H.-J. Lee, M. Kawasaki, T.G. Langdon, Mater. Sci. Eng. A 2015, 635, 109.

[43] J.Y. Kang, J.G. Kim, H.W. Park, H.S. Kim, Sci. Rep. 2016 DOI:10.1038/srep26590 
[44] P.Y. Chen, J. McKittrick, M.A. Meyers, Prog. Mater. Sci. 2012, 57, 1492.

[45] T.H. Fang, W.L. Li, N. R. Tao, K. Lu, Science 2011, 331, 1587.

[46] X.L. Wu, P. Jiang, L. Chen, F.P. Yuan, Y.T. Zhu, P. Natl. Acad. Sci. USA. 2011, 111, 7197.

[47] K. Lu, Science 2014, 345, 1455.

[48] X. L. Wu, P. Jiang, L. Chen, J. F. Zhang, F. P. Yuan, Y. T. Zhu, Mater. Res. Lett. 2015, 2185 .

[49] W.C. Oliver, G.M. Pharr, J. Mater. Res. 1992, 7, 1564.

[50] W.C. Oliver, G.M. Pharr, J. Mater. Res. 2002, 19, 3.

[51] A.C. Fischer-Cripps, Nanoindentation, Springer, New York, USA 2002

[52] K. Durst, V. Maier, Curr. Opin. Solid State Mater. Sci. 2015, 19, 340.

[53] J.M. Wheeler, D.E.J. Armstrong, W. Heinz, R. Schwaiger, Curr. Opin. Solid State Mater. Sci. 2015, 19, 354.

[54] N.Q. Chinh, R.Z. Valiev, X. Sauvage, G. Varga, K. Havancsák, M. Kawasaki, B.B. Straumal, T.G. Langdon, Adv. Eng. Mater. 2014, 16, 1000.

[55] J.-I. Jang, S. Shim, S.-I. Komazaki, T. Honda, J. Mater. Res. 2007, 22, 175.

[56] N.X. Zhang, N.Q. Chinh, M. Kawasaki, Y. Huang, T.G. Langdon, Mater. Sci. Eng. A 2016, 666, 350 .

[57] W.D. Nix, H. Gao, J. Mech. Phys. Solids 1998, 46, 411.

[58] D. Kiener, K. Durst, M. Rester, A.M. Minor, JOM 2009, 61(3), 14.

[59] G.M. Pharr, E.G. Herbert, Y. Gao, Ann. Rev. Mater. Res. 2010, 40, 271.

[60] N.Q. Chinh, P. Szommer, Mater. Sci. Eng. A 2014, 611, 333.

[61] D.-H. Lee, M.-Y. Seok, Y. Zhao, I.-C. Choi, J. He, Z. Lu, J.-Y. Suh, U. Ramamurty, M. Kawasaki, T.G. Langdon, J.-I. Jang, Acta Mater. 2016, 109, 314.

[62] Q. Wei, S. Cheng, K.T. Ramesh, E. Ma, Mater. Sci. Eng. A 2004, 381, 71.

[63] I.-C. Choi, Y.-J. Kim, Y.M. Wang, U. Ramamurty, J.-I. Jang, Acta Mater. 2013, 61, 7313.

[64] S. Shim, J.-I. Jang, G.M. Pharr, Acta Mater. 2008, 56, 3824.

[65] C.L. Wang, Y.H. Lai, J.C. Huang, T.G. Nieh, Scripta Mater. 2010, 62, 175. 
[66] I.-C. Choi, Y.-J. Kim, B. Ahn, M. Kawasaki, T.G. Langdon, J.-I. Jang, Scripta Mater. 2014, 75, 102.

[67] D.-H. Lee, I.-C. Choi, M.-Y. Seok, J. He, Z. Lu, J.-Y. Suh, M. Kawasaki, T.G. Langdon, J.-I. Jang, J. Mater. Res. 2015, 30, 2804.

[68] H. Conrad, Mater. Sci. Eng. A 2003, 341, 216.

[69] H. Conrad. Nanotechnology 2007, 18, 325701.

[70] H.J. Frost and M.F. Ashby: Deformation-Mechanism Maps: The Plasticity and Creep of Metals and Ceramics, Pergamon Press, Oxford, UK 1982.

[71] D.A. Woodford, Trans. ASM 1969, 62, 291.

[72] T.G. Langdon, Scripta Metall. 1977, 11, 997.

[73] Y.M. Wang, E. Ma, Mater. Sci. Eng. A 2004, 375-377, 46.

[74] T. Zhu, J. Li, A. Samanta, H.G. Kim, S. Suresh, PNAS 2007, 104, 3031.

[75] L. Lu, S.X. Li, K. Lu, Scripta Mater. 2001, 45, 1163.

[76] F. Dalla Torre, H. Van Swygenhoven, M. Victoria, Acta Mater. 2002, 50, 3957.

[77] R. Schwaiger, B. Moser, M. Dao, N. Chollacoop, S. Suresh, Acta Mater. 2003, 51, 5159.

[78] J. Mueller, K. Durst, D. Amberger, M. Göken, Mater. Sci. Forum 2006, 503-504, 31.

[79] V. Maier, K. Durst, J. Mueller, B. Backes, H.W. Höppel, M. Göken, J. Mater. Res. 2011, 26, 1421.

[80] H.W. Höppel, J. May, M. Göken, Adv. Eng. Mater. 2004, 6, 781.

[81] J. Chen, L. Lu, K. Lu, Scripta Mater. 2006, 54, 1913.

[82] J. Alkorta, J.M Martínez-Esnaola, J.G. Sevillano, Acta Mater. 2008, 56, 884.

[83] J.M. Wheeler, V. Maier, K. Durst, M. Göken, J. Michler, Mater. Sci. Eng. A 2013, 585, 108.

[84] T.G. Langdon, Acta Mater. 2013, 61, 7035.

[85] I.-C. Choi, D.-H. Lee, B. Ahn, K. Durst, M. Kawasaki, T.G. Langdon, J.-I. Jang, Scripta Mater. 2015, 94, 44.

[86] R.B. Figueiredo, T.G. Langdon, J. Mater. Sci. 2010, 45, 4827. 
[87] H. Somekawa, C.A. Schuh, Acta Mater. 2011, 59, 7554.

[88] O.A. Kaibyshev, B.V. Rodionov, R.Z. Valiev, Acta Metall. Mater. 1978, 26, 1877.

[89] M. Demirtas, G. Purcek, H. Yanar, Z.J. Zhang, Z.F. Zhang, Mater. Sci. Eng. A 2015, $620,233$.

[90] T. Uesugi, M. Kawasaki, M. Ninomiya, Y. Kamiya, Y. Takigawa, K. Higashi, Mater. Sci. Eng. A 2015, 645, 47.

[91] T. Tanaka, K. Makii, A. Kushibe, M. Kohzu, K. Higashi, Scripta Mater. 2003, 49, 361.

[92] T. Tanaka, M. Kohzu, Y. Takigawa, K. Higashi, Scripta Mater. 2005, 52, 231.

[93] M. Kawasaki, B. Ahn, T.G. Langdon, Acta Mater. 2010, 58, 919.

[94] V. Maier, B. Merle, M. Göken, K. Durst, J. Mater. Res. 2013, 28, 1177.

[95] N.Q. Chinh, P. Szommer, Z. Horita, T.G. Langdon, Adv. Mater. 2006, 18, 34.

[96] H.-J. Lee, S.K. Lee, K.H. Jung, G.A. Lee, B. Ahn, M. Kawasaki, T.G. Langdon, Mater. Sci. Eng. A 2015, 630, 90.

[97] M. Kawasaki, J. Mater. Sci. 2014, 49, 18.

[98] M. Furukawa, Z. Horita, M. Nemoto, R.Z. Valiev, T.G. Langdon, J. Mater. Res. 1996, $11,2128$.

[99] T.-S. Cho, H.-J. Lee, B. Ahn, M. Kawasaki, T.G. Langdon, Acta Mater. 2014, 72, 67.

[100] N.X. Zhang, M. Kawasaki, Y. Huang, T.G. Langdon, J. Mater. Sci. 2013, 48, 4582.

[101] Q.H. Tang, Y. Huang, Y.Y. Huang, X.Z. Liao, T.G. Langdon, P.Q. Dai, Mater. Lett. $\mathbf{2 0 1 5}, 151,126$.

[102] B. Schuh, F. Mendez-Martin, B. Völker, E.P. George, H. Clemens, R. Pippan, A. Hohenwarter, Acta Mater. 2015, 96, 258.

[103] M. Kawasaki, B. Ahn, H.-J. Lee, A.P. Zhilyaev, T.G. Langdon, J. Mater. Res. 2016, 31,88 .

[104] B. Ahn, H.-J. Lee, I.-C. Choi, M. Kawasaki, J.-I. Jang, T.G. Langdon, Adv. Eng. Mater. 2016, 18, 1001.

[105] M. Kawasaki, S.N. Alhajeri, C. Xu, T.G. Langdon, Mater. Sci. Eng. A 2011, 529, 345.

[106] D. Jia, Y.M. Wang, K.T. Ramesh, E. Ma, Y.T. Zhu, R.Z. Valiev, Applied Phys. Lett. 2001, 79, 611 . 
[107] B.Q. Han, F.A. Mohamed, Z. Lee, S.R. Nutt, E.J. Lavernia, Metall. Mater. Trans. A 2003, 34, 603 .

[108] B.Q. Han, J. Huang, Y.T. Zhu, E.J. Lavernia, Adv. Eng. Mater. 2006, 8, 945.

[109] R.C. Picu, Acta Mater. 2004, 52, 3447.

[110] H. Zhang, K.T. Ramesh, E.S.C. Chin, Mater. Sci. Eng. A 2004, 384, 26.

[111] X. Sauvage, G. Wilde, S.V. Divinski, Z. Horita, R.Z. Valiev, Mater. Sci. Eng. A 2012, 540,1 .

[112] K. Lu, L. Lu, S. Suresh, Science 2009, 324, 349.

[113] N.Q. Chinh, P. Szommer, T. Csanádi, T.G. Langdon, Mater. Sci. Eng. A 2006, 434, 326.

[114] H. Miyamoto, K. Ota, T. Mimaki, Scripta Mater. 2006, 54, 1721.

[115] M. Wang, A. Shan, J. Alloys Compd. 2008, 455, L10.

[116] M. Ruppert, W. Böhm, H. Nguyen, H.W. Höppel, M. Merklein, M. Göken, J. Mater. Sci. 2013, 48, 8377.

[117] M.S. Mohebbi, A. Akbarzadeh, B.H. Kim, S.-K. Kim, Metall. Mater. Trans. A 2014, 45,5442 .

[118] M. Hockauf, L.W. Meyer, J. Mater. Sci. 2010, 45, 4778.

[119] R.Z. Valiev, N.A. Enikeev, M.Y. Murashkin, V.U. Kazykhanov, X. Sauvage, Scripta Mater. 2010, 63, 949.

[120] T.G. Karnavskaya, E.V. Avtokratova, A.M. Bragov, M.V. Markushev, O.S. Sitdikov, V.N. Perevezentsev, M.Y. Shcherban, Tech. Phys. Lett. 2012, 38, 620.

[121] L.W. Meyer, M. Hockauf, L. Krüger, I. Schneider, Int. J. Mat. Res. 2007, 98, 191.

[122] I. Sabirov, Y. Estrin, M.R. Barnett, I. Timokhina, P.D. Hodgson, Scripta Mater. 2008, $58,163$.

[123] I. Sabirov, M.R. Barnett, Y. Estrin, P.D. Hodgson, Scripta Mater. 2009, 61, 181.

[124] I. Sabirov, M.R. Barnett, Y. Estrin, I. Timokhina, P.D. Hodgson, Int. J. Mat. Res. 2009, $100,1679$.

[125] R.Z. Valiev, M.Y. Murashkin, A. Kilmametov, B. Straumal, N.Q. Chinh, T.G. Langdon, J. Mater. Sci. 2010, 45, 4718.

[126] N.Q. Chinh, T. Csanádi, T. Györi, R.Z. Valiev, B.B. Straumal, M. Kawasaki, T.G. Langdon, Mater. Sci. Eng. A 2013, 543, 117. 
[127] E.V. Bobruk, X. Sauvage, N.A. Enikeev, B.B. Straumal, R.Z. Valiev, Rev. Adv. Mater. Sci. 2015, 43, 45.

[128] G.T. Gray III, T.C. Lowe, C.M. Cady, R.Z. Valiev, I.V. Aleksandrov, Nanostruct. Mater. 1997, 9, 477.

[129] Y.M. Wang, E. Ma, Applied Phys. lett. 2003, 83, 3165.

[130] Y.J. Li, X.H. Zeng, W. Blum, Acta Mater. 2004, 52, 5009.

[131] Y.J. Li, W. Blum, Phys. Status Solidi. A 2005, 202, R119.

[132] F.H. Dalla Torre, E.V. Pereloma, C.H.J. Davies, Scripta Mater. 2004, 51, 367.

[133] F.H. Dalla Torre, E.V. Pereloma, C.H.J. Davies, Acta Mater. 2006, 54, 1135.

[134] Y.-H. Zhao, J.F. Bingert, X.-Z. Liao, B.-Z. Cui, K. Han, A.V. Sergueeva, A.K. Mukherjee, R.Z. Valiev, T.G. Langdon, Y.T. Zhu, Adv. Mater. 2006, 18, 2949.

[135] A. Mishra, M. Martin, N.N. Thadhani, B.K. Kad, E.A. Kenik, M.A. Meyers, Acta Mater. 2008, 56, 2770.

[136] Y. Zhao, Y. Li, T.D. Topping, X. Liao, Y. Zhu, R.Z. Valiev, E.J. Lavernia, Int. J. Mat. Res. 2009, 100, 1647.

[137] T. Kunimine, T. Fujii, S. Onaka, N. Tsuji, M. Kato, J. Mater. Sci. 2011, 46, 4290.

[138] V. Maier, A. Hohenwarter, R. Pippan, D. Kiener, Scripta Mater. 2015, 106, 42.

[139] Q. Wei, L. Kecskes, T. Jiao, K.T. Hartwig, K.T. Ramesh, E. Ma, Acta Mater. 2004, 52, 1859.

[140] F.H. Dalla Torre, A.C. Hänzi, P.J. Uggowitzer, Scripta Mater. 2008, 59, 207.

[141] F. Dalla Torre, P. Spätig, R. Schäublin, M. Victoria, Acta Mater. 2005, 53, 2337.

[142] Q. Wei, T. Jiao, S.N. Mathaudhu, E. Ma, K.T. Hartwig, K.T. Ramesh, Mater. Sci. Eng. A 2003, 358, 266.

[143] F.P.D. Lopes, C.H. Lu, S. Zhao, S.N. Monteiro, M.A. Meyers, Metall. Mater. Trans. A 2015, 46, 4468.

[144] Q. Wei, K.T. Ramesh, E. Ma, L.J. Kesckes, R.J. Dowding, V.U. Kazykhanov, R.Z. Valiev, Applied Phys. Lett. 2005, 86, 101907.

[145] Q. Wei, T. Jiao, K.T. Ramesh, E. Ma, L.J. Kecskes, L. Magness, R. Dowding, V.U. Kazykhanov, R.Z. Valiev, Acta Mater. 2006, 54, 77.

[146] Z. Pan, Y.Z. Guo, S.N. Mathaudhu, L.J. Kecskes, K.T. Hartwig, Q. Wei, J. Mater. Sci. 2008, 43,7379 . 
[147] M. Demirtas, G. Purcek, H. Yanar, Z.J. Zhang, Z.F. Zhang, J. Alloys Compd. 2015, $623,213$.

[148] T. Tanaka, K. Higashi, Mater. Trans. 2004, 45, 1261.

[149] T. Tanaka, H. Watanabe, M. Kohzu, K. Higashi, Mater. Sci. Forum 2004, 447-448, 489.

[150] S.H. Xia, J. Wang, J.T. Wang, J.Q. Liu, Mater. Sci. Eng. A 2008, 493, 111.

[151] Q. Wei, J. Mater. Sci. 2007, 42, 1709.

[152] Y.T. Zhu, T.C. Lowe, T.G. Langdon, Scripta Mater. 2004, 51, 825. 


\section{Figures and captions}

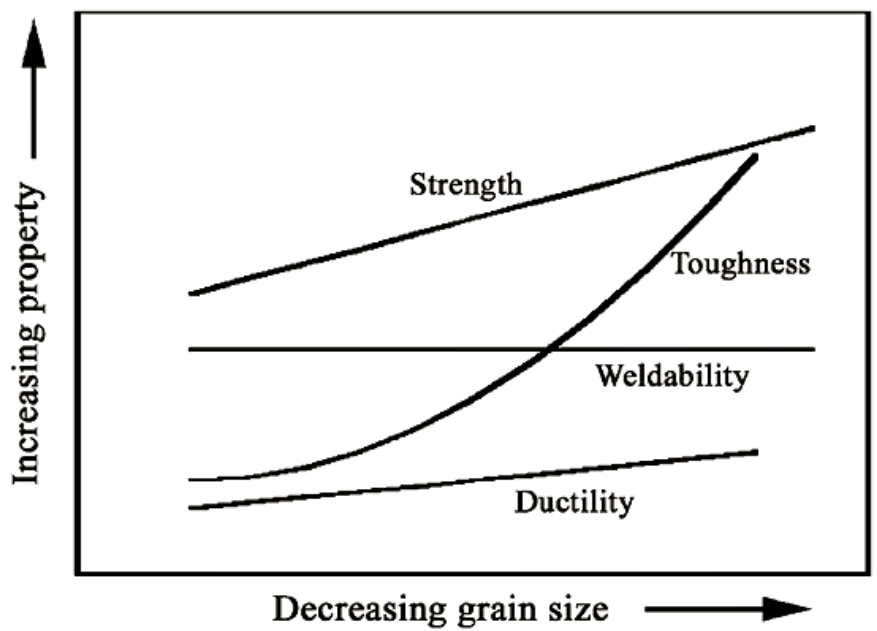

Figure 1. A schematic plot showing the effect of decreasing grain size on several material properties [3].

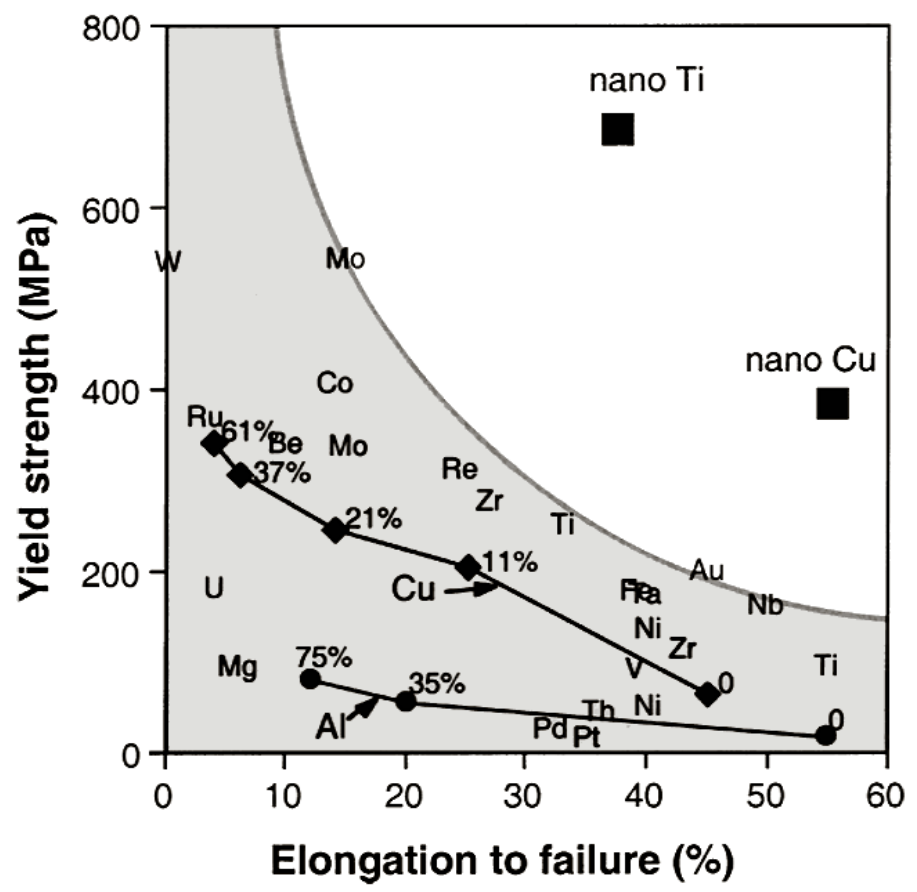

Figure 2. Conventional plot of yield stress against elongation to failure demonstrating the paradox of strength and ductility [18]. 


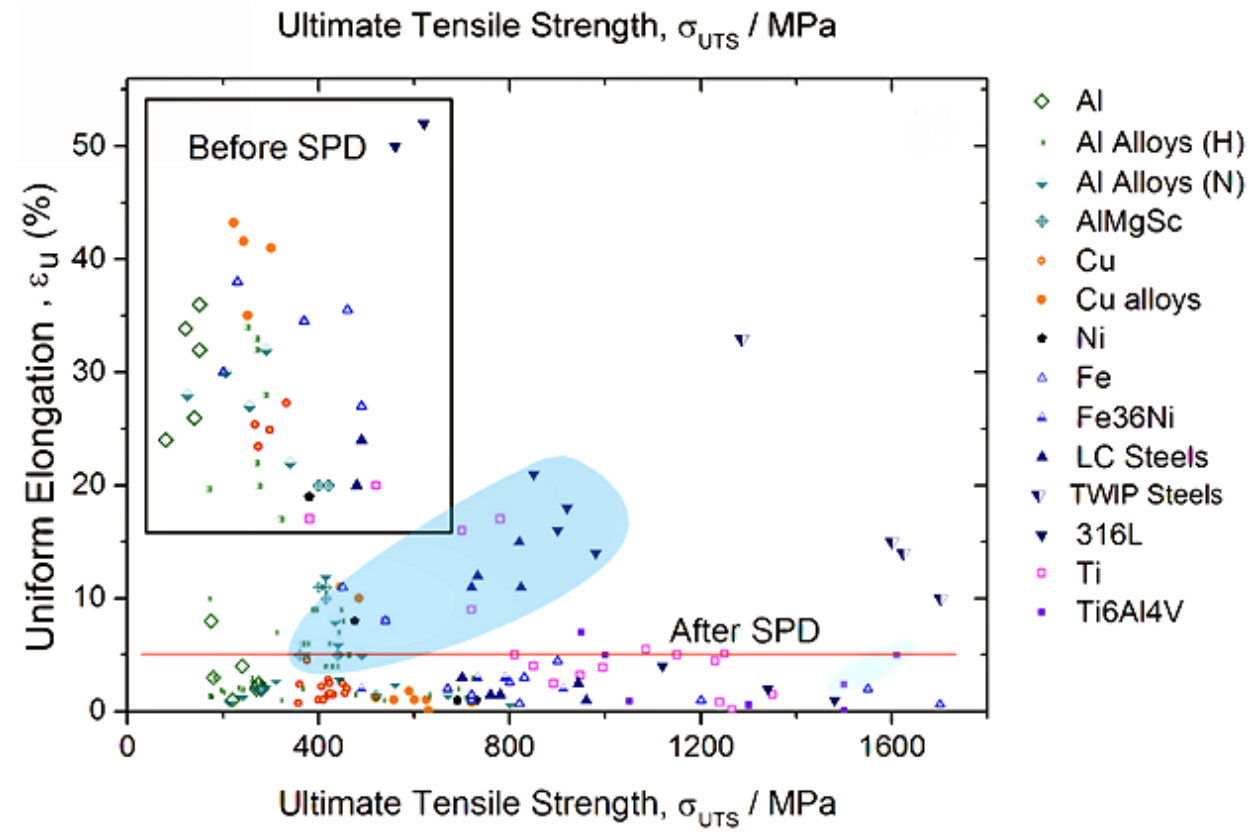

Figure 3. Schematic diagram revealing trends in the relationship between the ultimate tensile strength and ductility in various SPD materials where the blue region denotes the materials after short post-processing annealing [21].

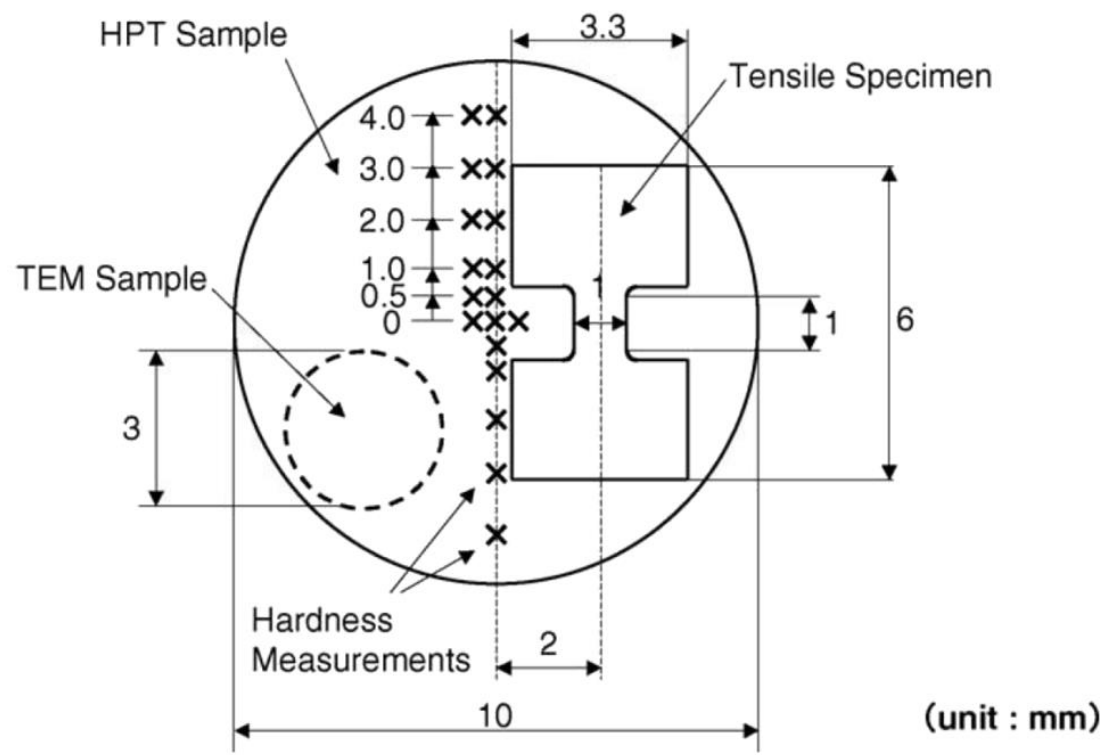

Figure 4. Schematic illustration of the typical miniature tensile specimen taken from offcenter of the HPT disk where two additional locations for hardness testing and TEM observation are included in the drawing [39]. 


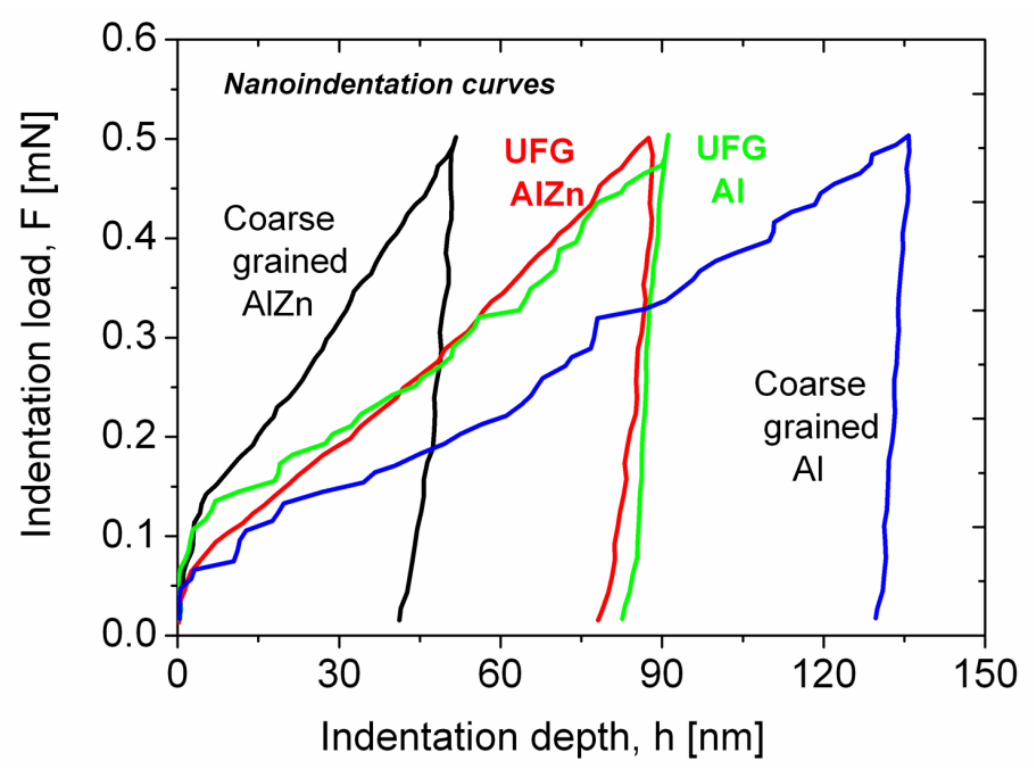

Figure 5. Load-displacement curves for pure $\mathrm{Al}$ and an $\mathrm{Al}-\mathrm{Zn}$ alloy having different grain sizes [54].

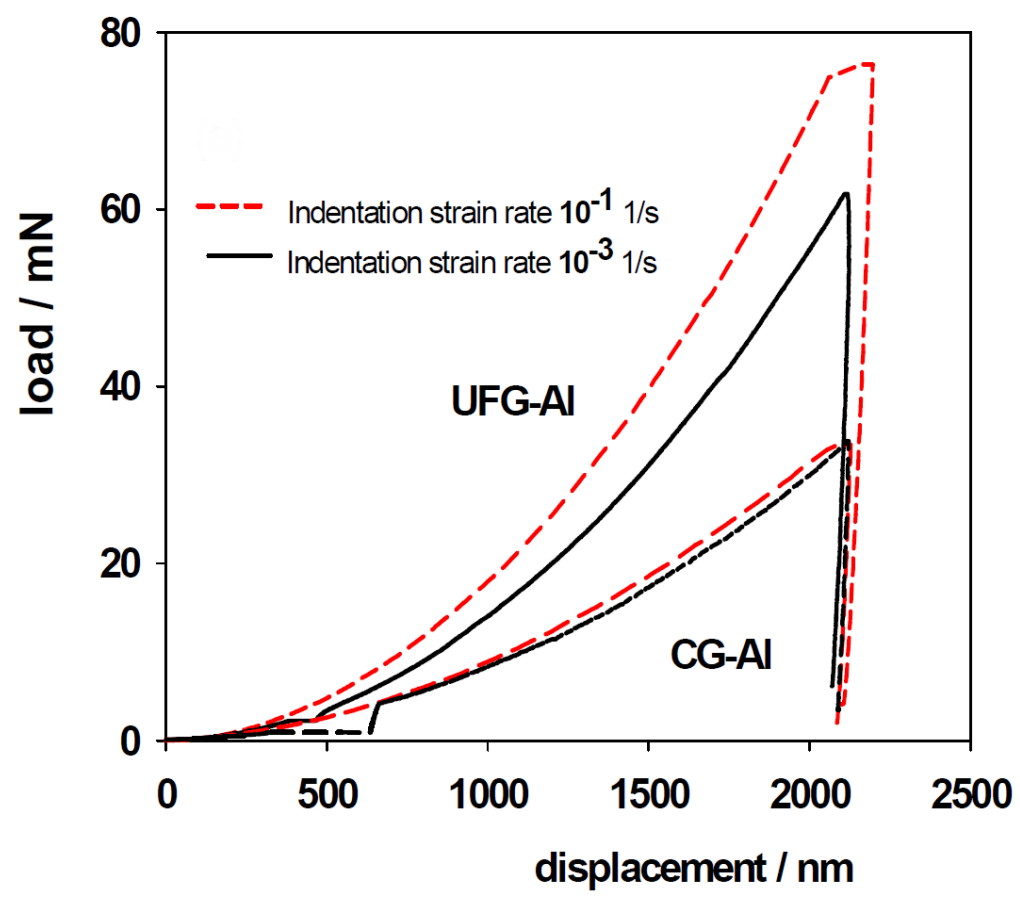

Figure 6. Load-displacement curves at different indentation strain rates demonstrating the indentation strain rate sensitivity for UFG- and CG-Al [78]. 


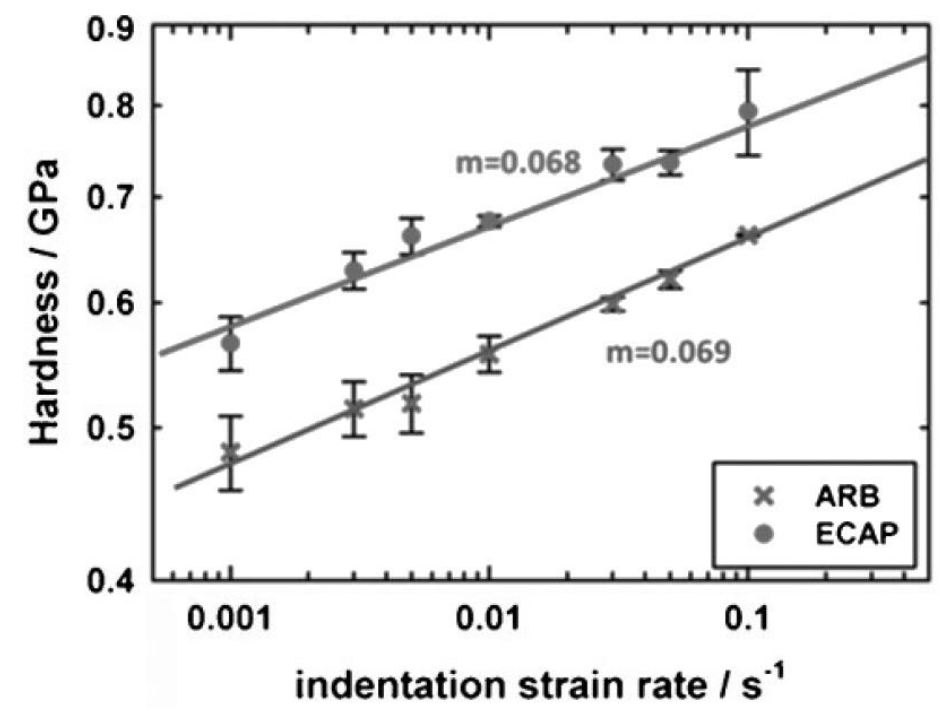

Figure 7. Determination of the strain rate sensitivity from the local measurements through nanoindentation for UFG-Al processed by ARB and ECAP [31].
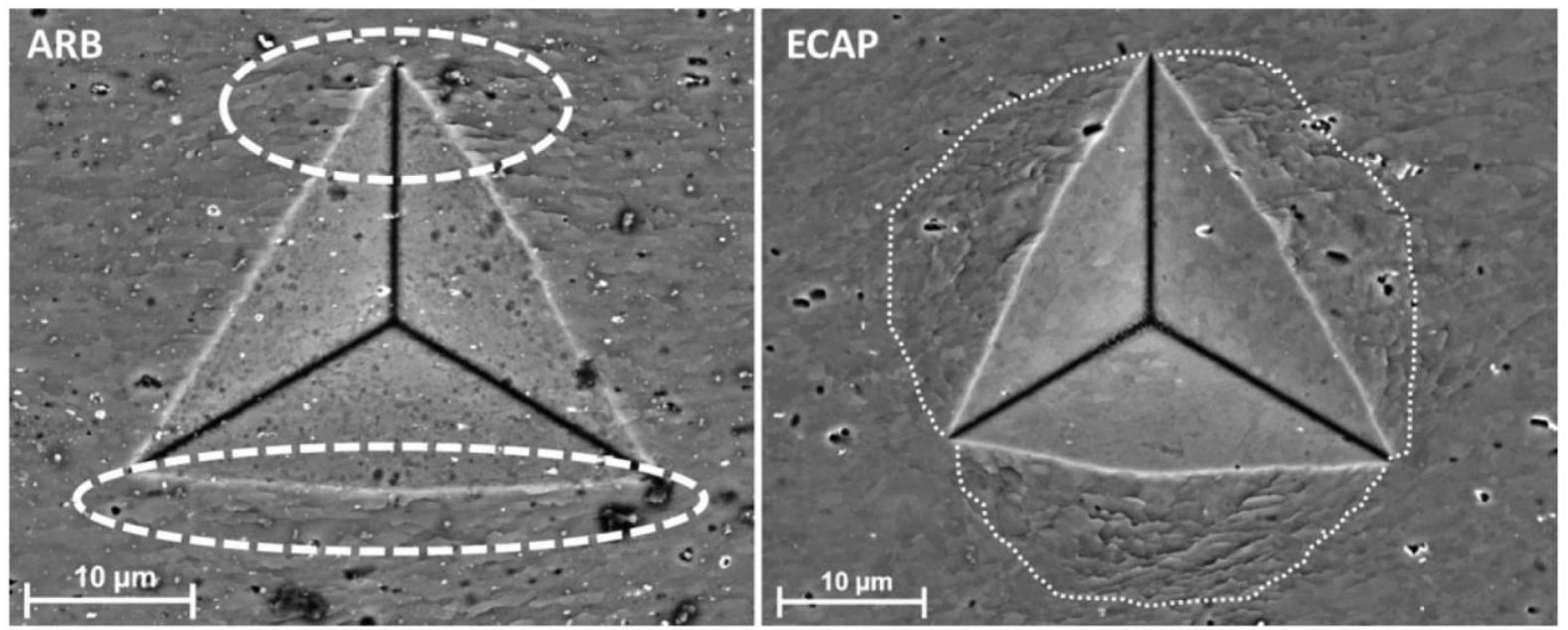

Figure 8. SEM images of nanoindentation indents in an ARB-processed $\mathrm{Al}$ (left) and an ECAP-processed $\mathrm{Al}$ (right) [31]. 


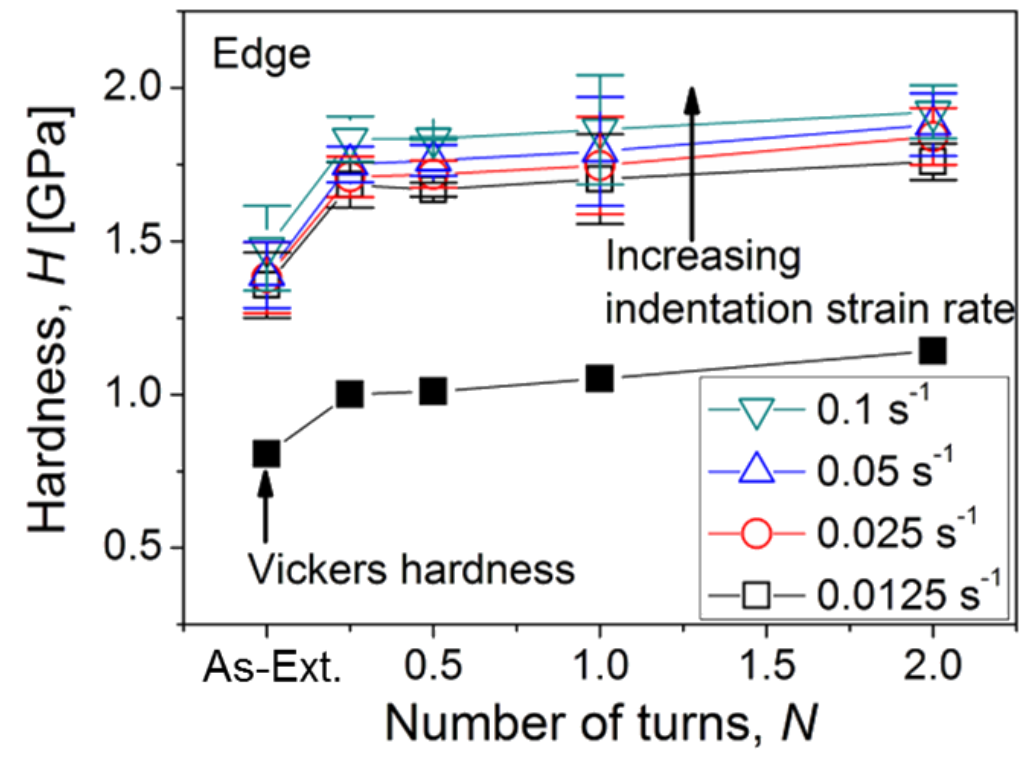

Figure 9. Variations in nanohardness and Vickers microhardness as a function of the number of HPT turns for a ZK60 magnesium alloy: "As-Ext." denotes the as-extruded condition [85].

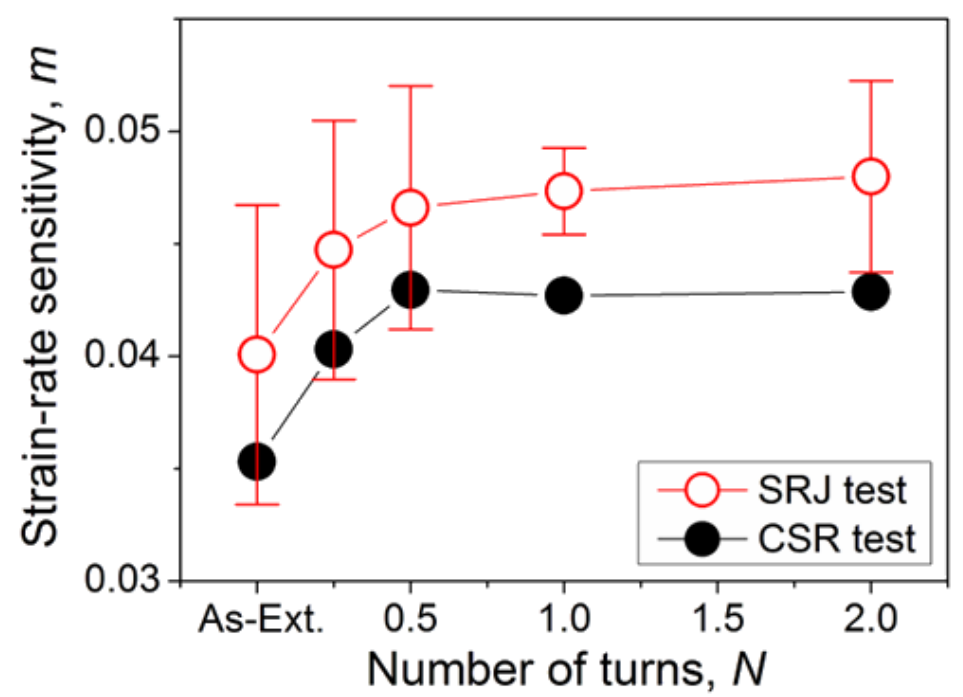

Figure 10. Variations of the strain-rate sensitivity with different levels of torsion straining for a ZK60 magnesium alloy: data were obtained through CSR and SRJ testing [85]. 


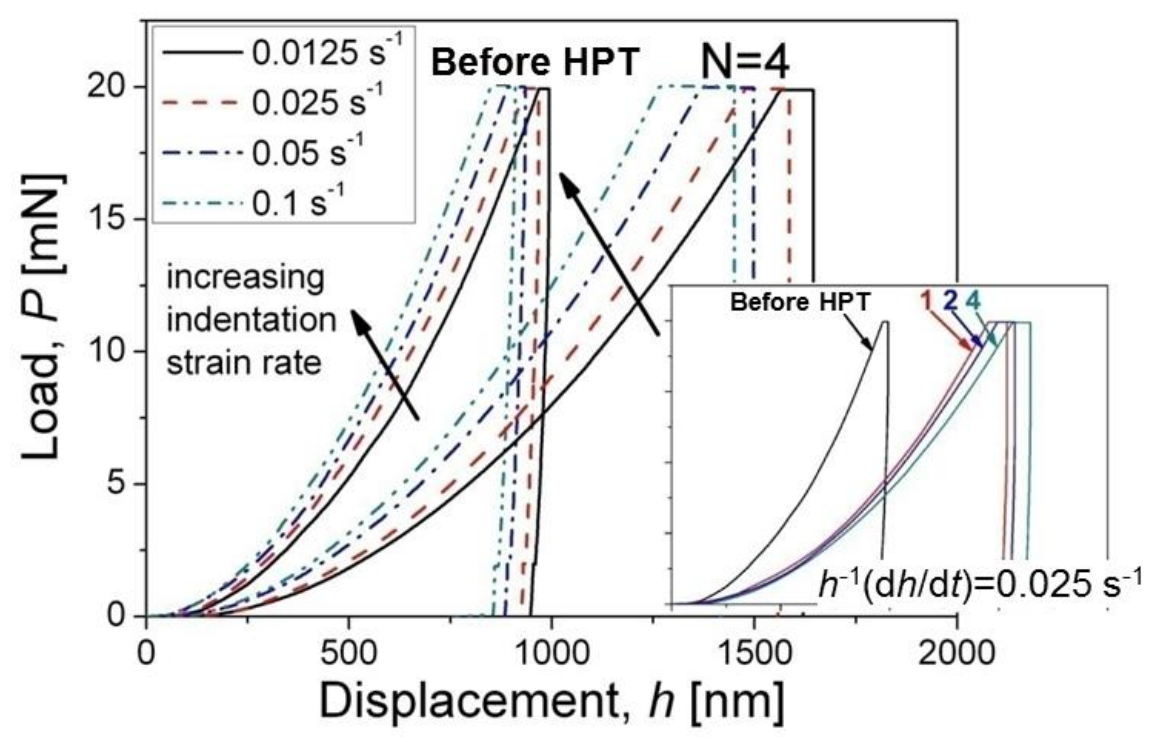

Figure 11. Typical $P-h$ curves obtained at different indentation rates for a $\mathrm{Zn}-22 \% \mathrm{Al}$ alloy in an as-annealed condition and after HPT for 4 turns where an inset image shows the change in the curve with the number of turns at an indentation strain rate of $0.025 \mathrm{~s}^{-1}$ [66].
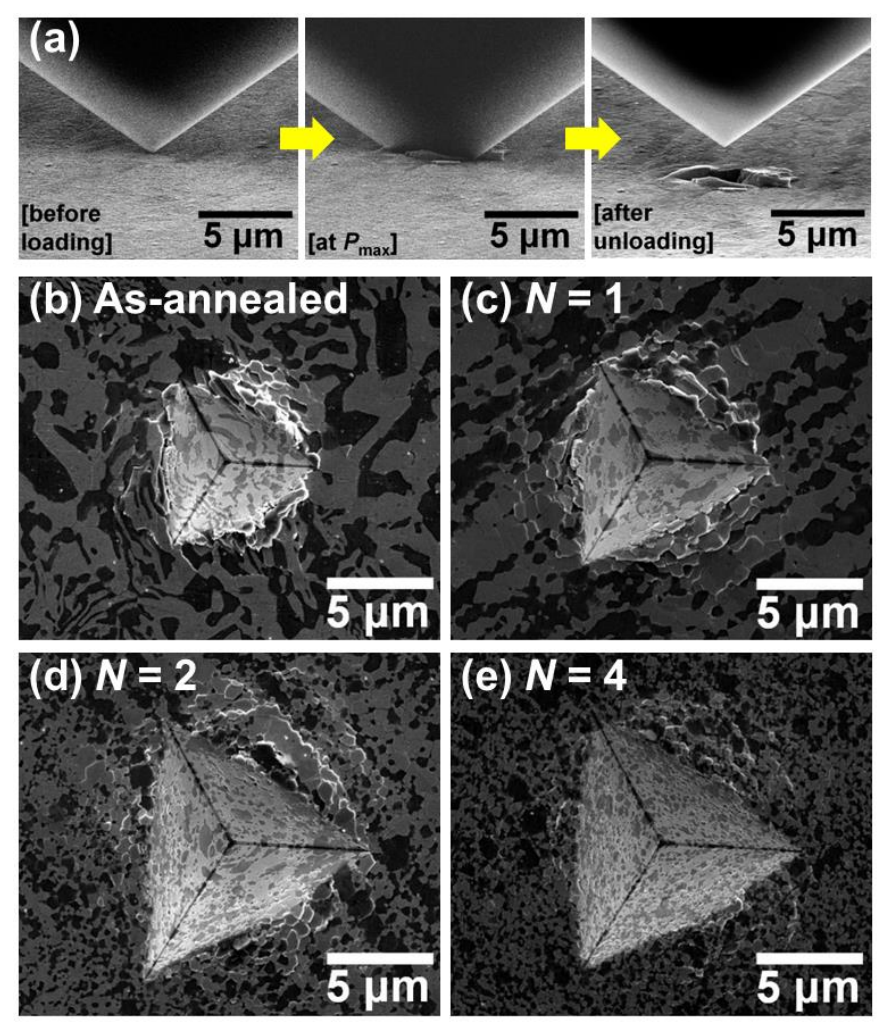

Figure 12. (a) In-situ nanoindentation images of the $\mathrm{Zn}-22 \% \mathrm{Al}$ alloy after annealing without HPT and SEM images of the indentations taken under $P_{\max }=20 \mathrm{mN}$ at $\dot{\varepsilon}_{i}=0.025 \mathrm{~s}^{-1}$ for (b) the as-annealed sample without HPT and the alloy after HPT for (c) 1 turn, (d) 2 turns and (e) 4 turns [66]. 


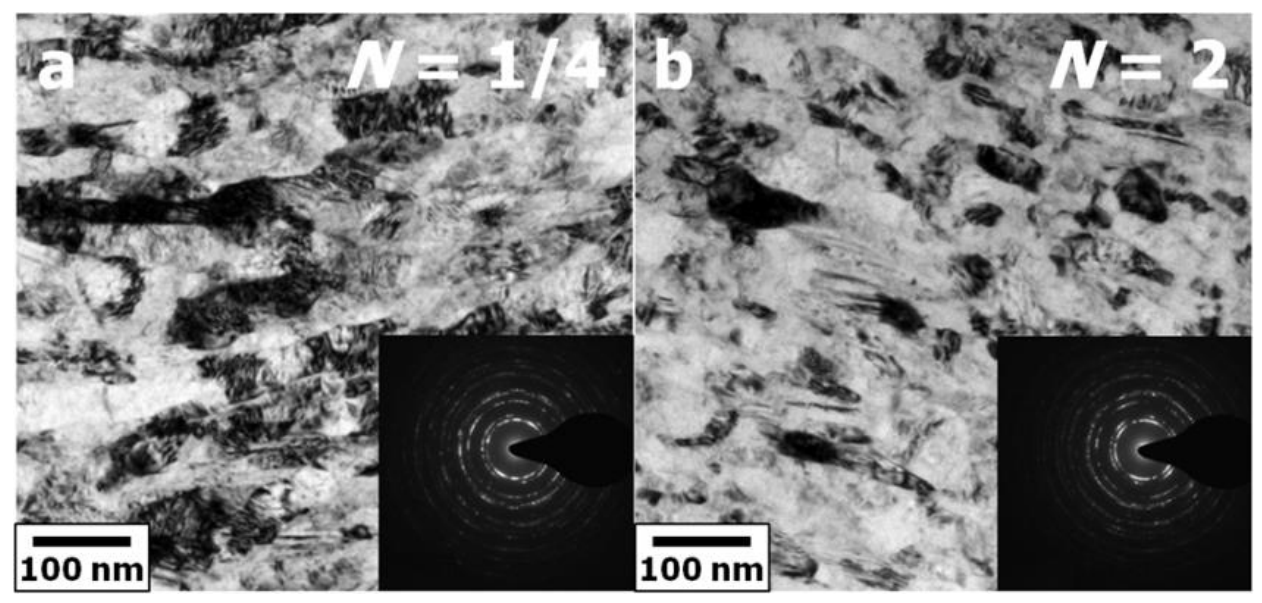

Figure 13. Representative TEM images and SAD patterns (inset) taken at the edges of the HEA disks after HPT for (a) 1/4 and (b) 2 turns [61,67].

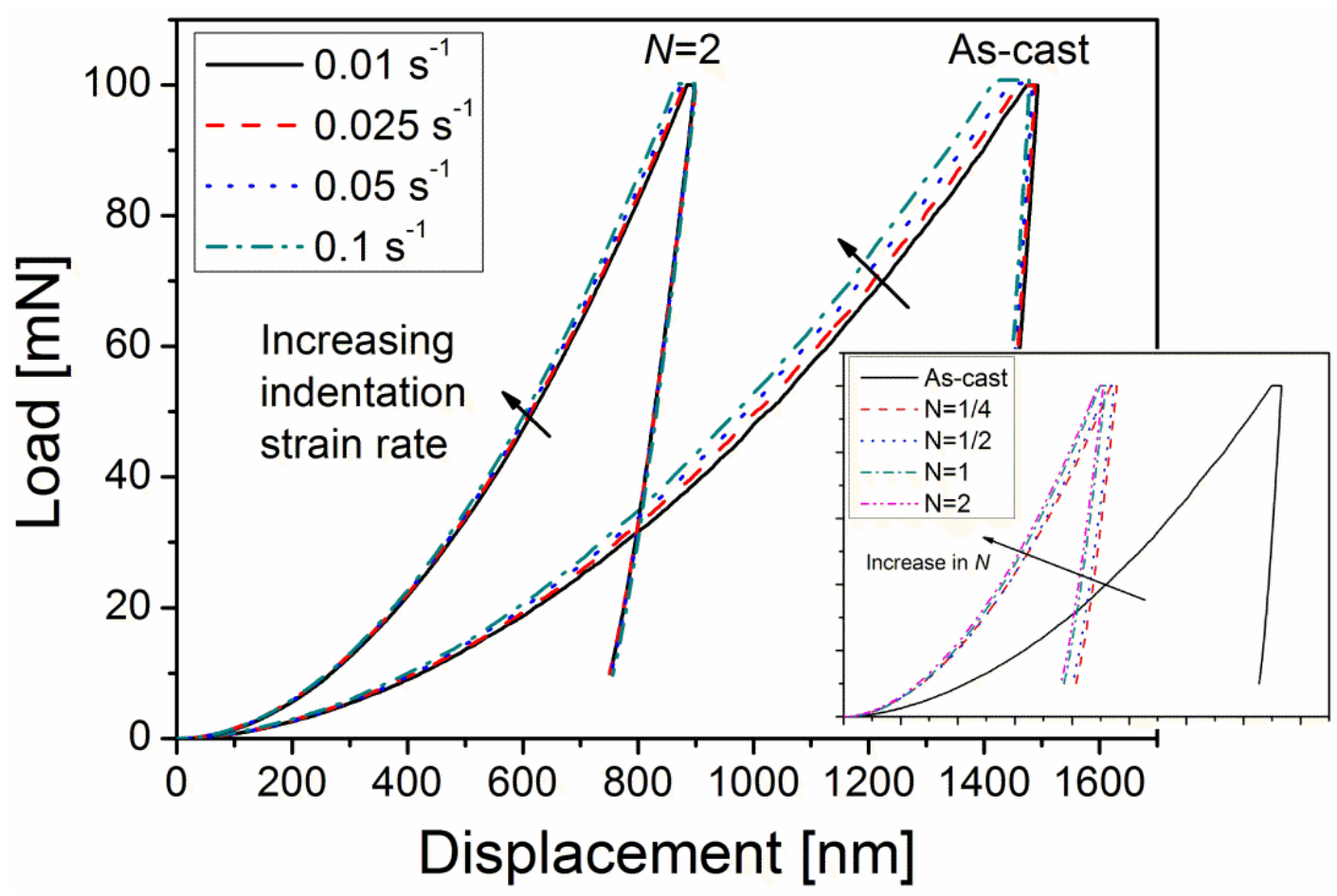

Figure 14. Representative $P$ - $h$ curves obtained at different indentation rates for the as-cast condition and $N=2$ turns with inset image showing the variation in the curve with increasing HPT turns at a fixed strain rate of $0.025 \mathrm{~s}^{-1}$ [67]. 


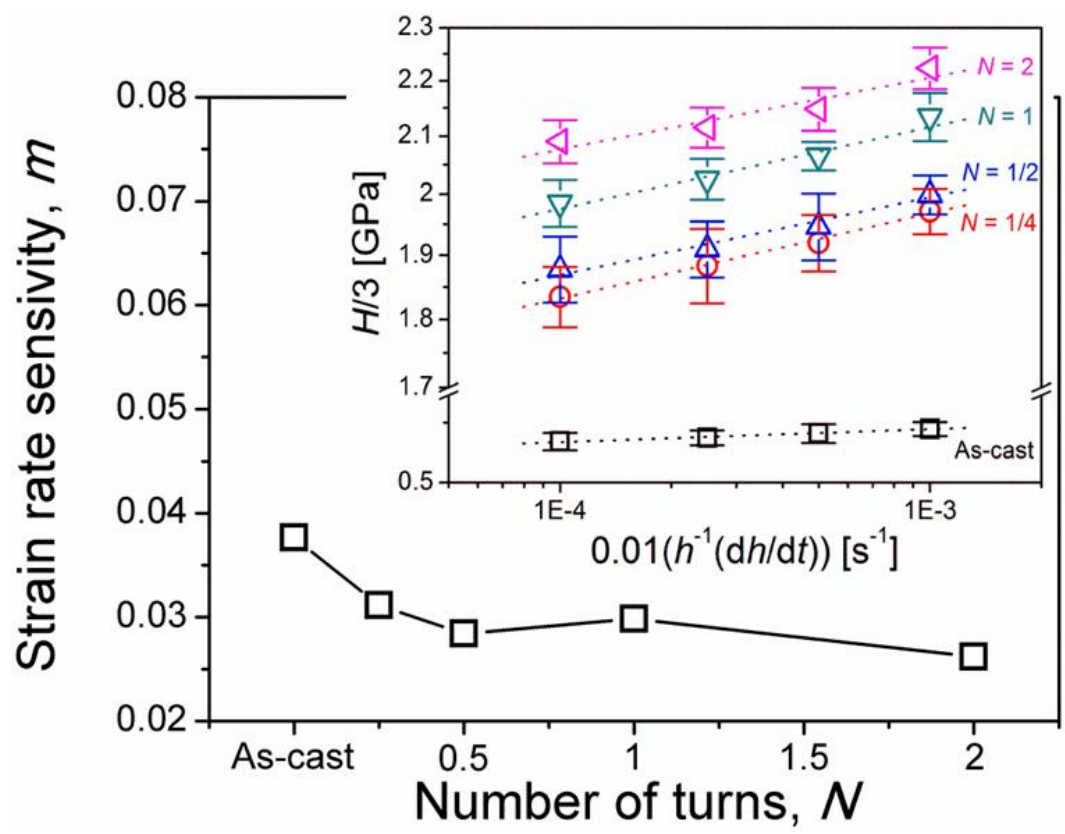

Figure 15. Variation in $\mathrm{m}$ for the HEA before and after HPT for increasing numbers of turns: Inset showing $H / 3$ vs. strain rate for the samples through 2 HPT turns [67].

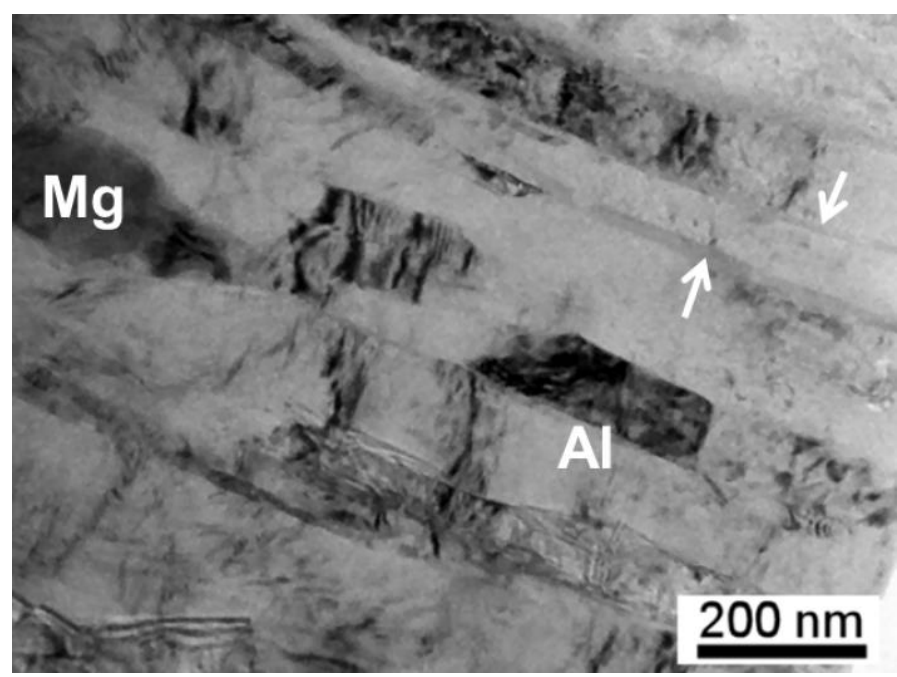

Figure 16. Bright-field TEM micrograph of an Al-Mg system taken at the disk edge after HPT for 5 turns showing a layered microstructure consisting of an $\mathrm{Al}$ matrix region (including one visible $\mathrm{Mg}$ phase) with $90-120 \mathrm{~nm}$ width and thin layers (white arrows) of $\mathrm{Al}_{3} \mathrm{Mg}_{2}$ with $20 \mathrm{~nm}$ width [42,103,104]. 


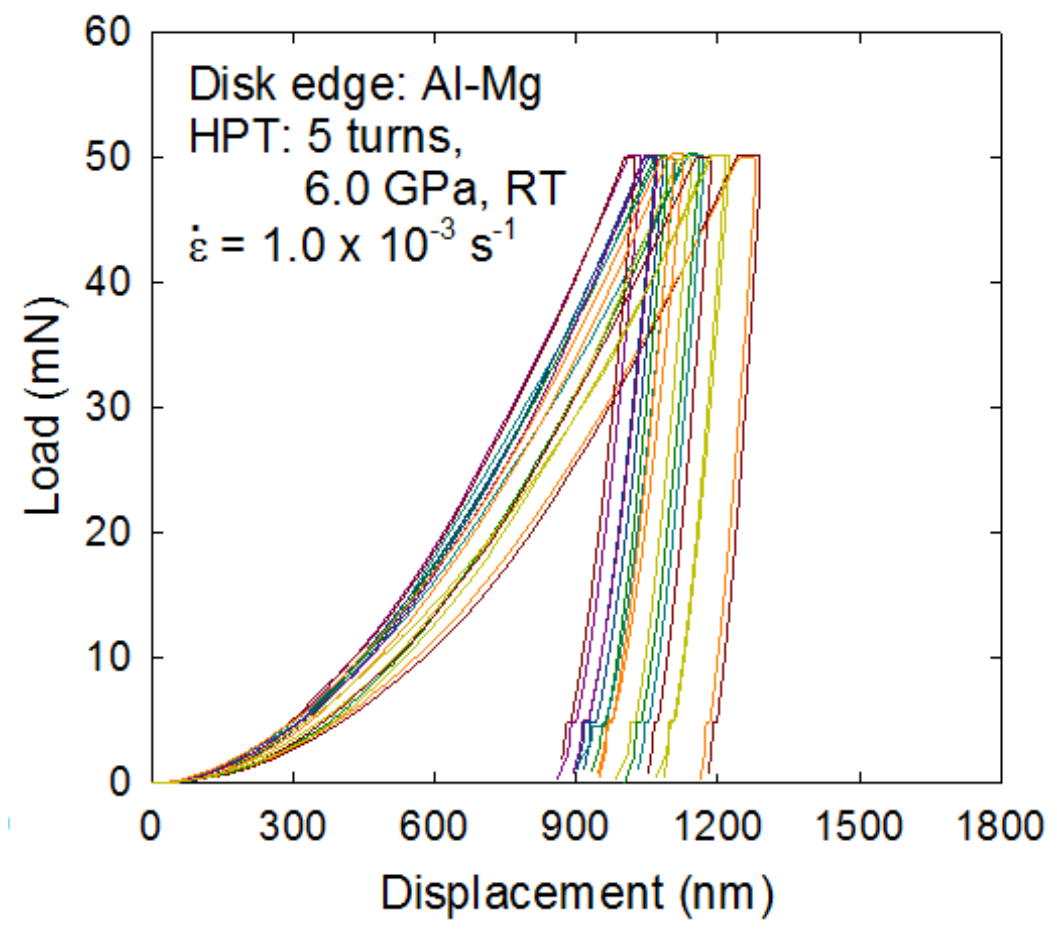

Figure 17. Representative $P-h$ curves obtained through nanoindentation taken at the disk edge of the Al-Mg system after HPT for 5 turn when testing at $1.0 \times 10^{-3} \mathrm{~s}^{-1}$ [104].

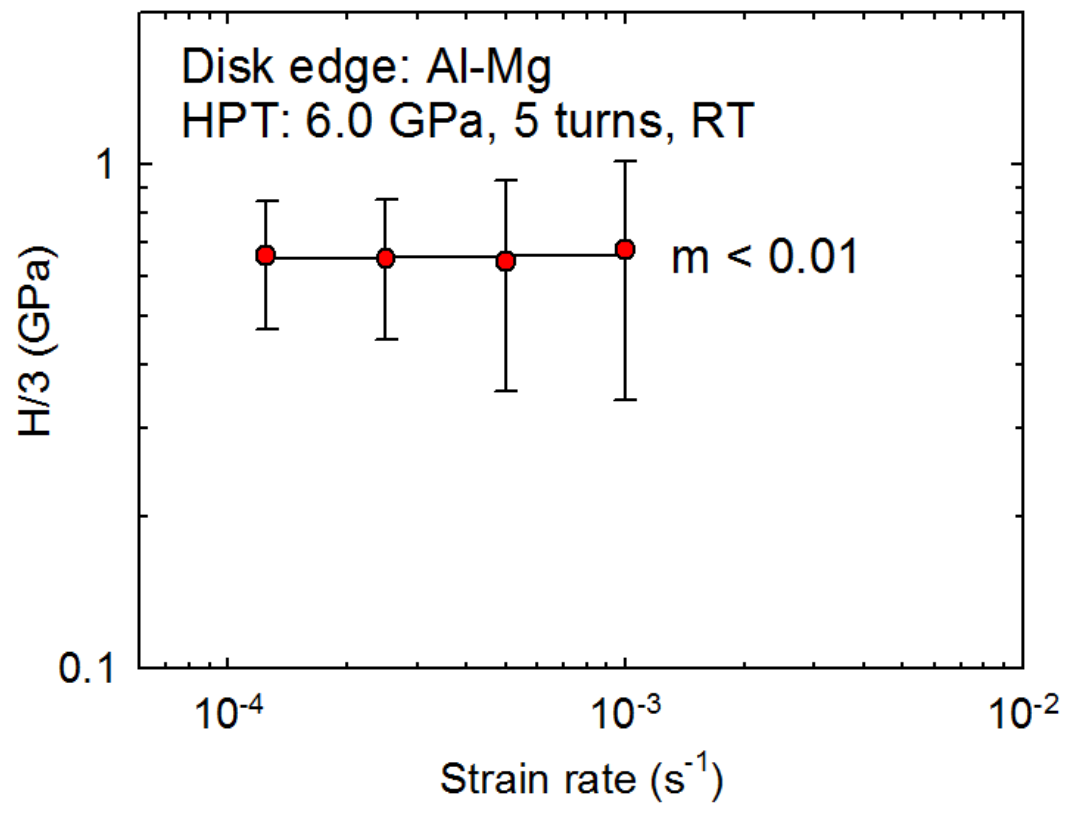

Figure 18. Distribution of the $m$ value for the Al-Mg system at the edge of the disk after HPT for 5 turns [104]. 

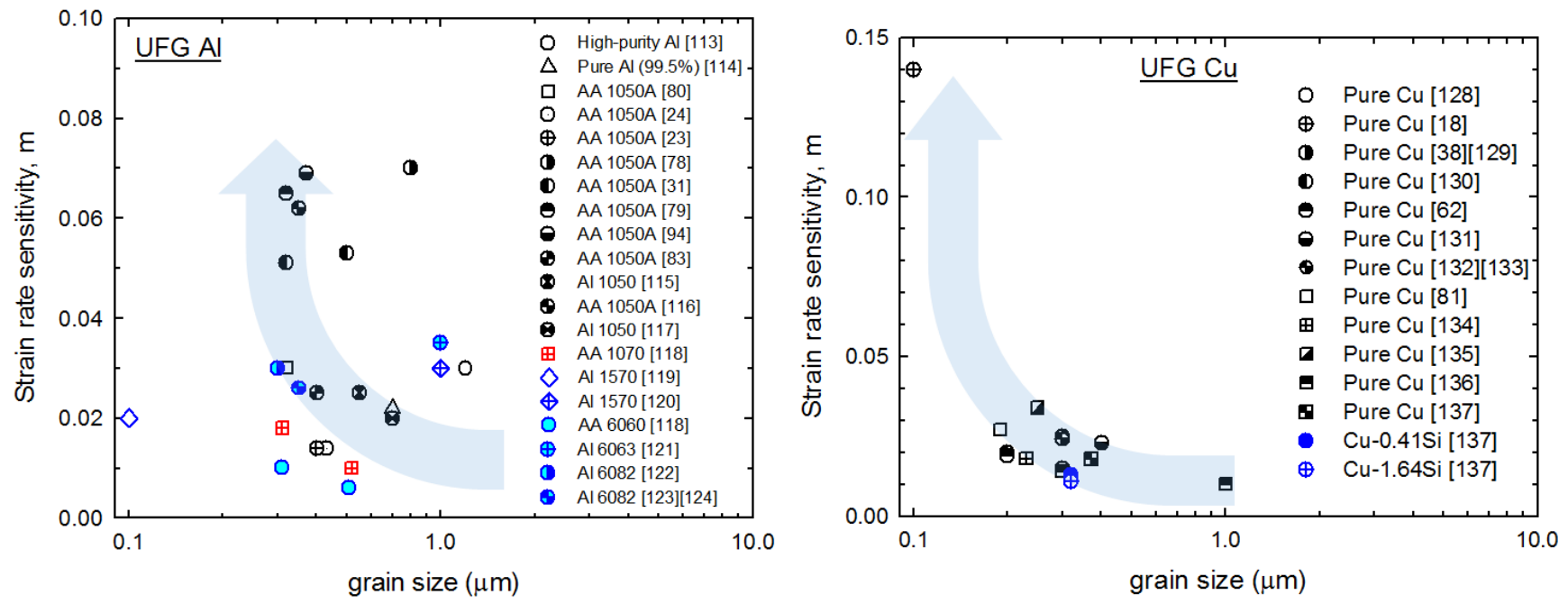

Figure 19. Strain rate sensitivity, $m$, of (a) UFG $\mathrm{Al}$ and (b) UFG $\mathrm{Cu}$ as a function of grain size. The trend of change in the $m$ value with reduction in grain size is denoted by the grey arrow in each plot. 
Table 1. A list of UFG materials processed by various SPD techniques showing strain rate sensitivity, $m$, at specific strain rate ranges at room temperature measured in different testing methods and conditions. [C: compression test, $\mathrm{T}$ : tensile test, $\mathrm{M}$ : microindentation test, $\mathrm{N}$ : nanoindentation test, CLR: constant loading rate condition, Creep: creep condition, CSR: constant strain rate condition, SRJ: strain rate jump test process]

\begin{tabular}{|c|c|c|c|c|c|c|}
\hline Material & Processing & $\begin{array}{l}\text { Grain size } \\
(\mu \mathrm{m})\end{array}$ & $\begin{array}{l}\text { Testing } \\
\text { method }\end{array}$ & $\begin{array}{l}\text { Strain rate } \\
\text { sensitivity, } m\end{array}$ & $\begin{array}{l}\text { Strain rate range } \\
\left(\mathrm{s}^{-1}\right)\end{array}$ & References \\
\hline $\begin{array}{l}\text { Pure Al } \\
(99.99 \%)\end{array}$ & ECAP for $8 \mathrm{p}$ at RT & 1.2 & C-CSR & 0.03 & $10^{-5}-10^{-2}$ & $\begin{array}{l}\text { Chinh et al.(2006) } \\
\text { [113] }\end{array}$ \\
\hline $\begin{array}{l}\text { Pure Al } \\
(99.5 \%)\end{array}$ & ECAP for $8 p$ at RT & 0.7 & T-CSR & 0.022 & $1.6 \times 10^{-3}-3.2 \times 10^{0}$ & $\begin{array}{l}\text { Miyamoto et al. } \\
(2006)[114]\end{array}$ \\
\hline AA $1050 \mathrm{~A}$ & ARB for 8 cycles at RT & 0.32 & T-CSR & 0.03 & $1 \times 10^{-5}-5 \times 10^{-3}$ & $\begin{array}{l}\text { Höppel et al. (2004) } \\
\text { [80] }\end{array}$ \\
\hline AA 1050 A & ECAP for $8 p$ at RT & 0.43 & C-SRJ & 0.014 & $10^{-5}-10^{-3}$ & $\begin{array}{l}\text { May etal. (2005) } \\
{[24]}\end{array}$ \\
\hline AA $1050 \mathrm{~A}$ & ECAP for $8 \mathrm{p}$ at RT & $0.27-0.43$ & C-SRJ & $0.01-0.014$ & $10^{-6}-10^{-3}$ & $\begin{array}{l}\text { Höppel et al. (2005) } \\
\text { [23] }\end{array}$ \\
\hline AA 1050A & ECAP for $12 \mathrm{p}$ at RT & 0.80 & N-CSR & 0.07 & $10^{-5}-10^{-3} *$ & $\begin{array}{l}\text { Mueller et al. (2006) } \\
\text { [78] }\end{array}$ \\
\hline \multirow[t]{4}{*}{ AA $1050 \mathrm{~A}$} & \multirow[t]{2}{*}{ ECAP for $6 p$ at RT } & \multirow[t]{2}{*}{0.50} & T-CSR & 0.053 & \multirow[t]{4}{*}{$10^{-5}-10^{-3} *$} & \multirow{4}{*}{$\begin{array}{l}\text { Böhner etal. (2011) } \\
\text { [31] }\end{array}$} \\
\hline & & & N-CSR & 0.068 & & \\
\hline & \multirow[t]{2}{*}{ ARB for 8 cycles at RT } & \multirow[t]{2}{*}{0.32} & $\mathrm{~T}-\mathrm{CSR}$ & 0.051 & & \\
\hline & & & N-CSR & 0.069 & & \\
\hline AA $1050 \mathrm{~A}$ & $\mathrm{ARB}$ for 8 cycles at RT & 0.32 & N-SRJ & $\begin{array}{l}0.065 \text { (bulk } \\
\text { phase), } 0.156 \\
\text { (bond layer) }\end{array}$ & $5 \times 10^{-4}-5 \times 10^{-2}$ & $\begin{array}{l}\text { Maier et al. (2011) } \\
\text { [79] }\end{array}$ \\
\hline AA $1050 \mathrm{~A}$ & ECAP for $8 \mathrm{p}$ at RT & 0.37 & $\mathrm{~N}-\mathrm{Cr}$ & 0.069 & $4 \times 10^{-6}-3 \times 10^{-3}$ & $\begin{array}{l}\text { Maier et al. (2013) } \\
\text { [94] }\end{array}$ \\
\hline AA $1050 \mathrm{~A}$ & ECAP for $8 \mathrm{p}$ at RT & 0.40 & N-SRJ & 0.025 & $2.5 \times 10^{-5}-2.5 \times 10^{4} *$ & $\begin{array}{l}\text { Wheeler etal. (2013) } \\
\text { [83] }\end{array}$ \\
\hline $\mathrm{Al} 1050$ & $\begin{array}{l}\text { ECAP for } 4 p \text { at } \mathrm{RT}+\text { Cold } \\
\text { rolling }\end{array}$ & $0.5-0.6$ & T-CSR & $0.02-0.039$ & $5 \times 10^{-5}-1 \times 10^{-1}$ & $\begin{array}{l}\text { Wang \& Shan (2008) } \\
\text { [115] }\end{array}$ \\
\hline AA $1050 \mathrm{~A}$ & ARB for 6 cycles at RT & $0.30-0.35$ & T-CSR & $0.060-0.062$ & $10^{-5}-10^{-3}$ & $\begin{array}{l}\text { Ruppert etal. (2013) } \\
\text { [116] }\end{array}$ \\
\hline Al 1050 & ARB for 8 cycles at RT & $0.3-0.7$ & T-CSR & 0.02 & $6.4 \times 10^{-3}-1.3 \times 10^{-1}$ & $\begin{array}{l}\text { Mohebbi et al. (2014) } \\
\text { [117] }\end{array}$ \\
\hline \multirow[t]{2}{*}{ AA 1070} & ECAP for $2 p$ at RT & 0.52 & \multirow[t]{4}{*}{$\mathrm{T}-\mathrm{CSR}$} & $0.01-0.017$ & \multirow[t]{4}{*}{$3 \times 10^{-4}-1 \times 10^{0}$} & \multirow{4}{*}{$\begin{array}{l}\text { Hockauf \& Meyer } \\
(2010)[118]\end{array}$} \\
\hline & ECAP for $8 p$ at RT & 0.31 & & 0.018 & & \\
\hline \multirow[t]{2}{*}{ AA 6060} & ECAP for $2 p$ at RT & 0.51 & & 0.006 & & \\
\hline & ECAP for $2 p$ at RT & 0.31 & & 0.010 & & \\
\hline Al 1570 & HPT for 20 turns at RT & 0.10 & $\mathrm{~T}-\mathrm{CSR}$ & 0.02 & $10^{-4}$ & $\begin{array}{l}\text { Valiev et al. (2010) } \\
\text { [119] }\end{array}$ \\
\hline Al 1570 & $\begin{array}{l}\text { ECAP (true logarithmic } \\
\text { strain of } 8 \text { ) at } 598 \mathrm{~K}\end{array}$ & $\begin{array}{l}1.0+20 \\
\text { (bimodal) }\end{array}$ & T-CSR & 0.03 & $1 \times 10^{3}-4 \times 10^{4}$ & $\begin{array}{l}\text { Karnavskaya et al. } \\
(2012)[120]\end{array}$ \\
\hline Al 6063 & ECAP for $8 \mathrm{p}$ at RT & 1.0 & $\mathrm{~T}-\mathrm{CSR}$ & 0.035 & $1.7 \times 10^{2}-2.8 \times 10^{3}$ & $\begin{array}{l}\text { Meyer et al. (2007) } \\
\text { [121] }\end{array}$ \\
\hline $\mathrm{Al} 6082$ & ECAP for $8 p$ at $373 \mathrm{~K}$ & $0.2-0.4$ & $\mathrm{~T}-\mathrm{SRJ}$ & 0.03 & $1.1 \times 10^{-5}-1.0 \times 10^{-2}$ & $\begin{array}{l}\text { Sabirov et al. (2008) } \\
\text { [122] }\end{array}$ \\
\hline
\end{tabular}




\begin{tabular}{|c|c|c|c|c|c|c|}
\hline Al 6082 & ECAP for $8 p$ at $373 \mathrm{~K}$ & $0.2-0.4$ & C-SRJ & $0.026-0.013$ & $10^{-5}-10^{-2}$ & $\begin{array}{l}\text { Sabirov et al. (2009) } \\
\text { [123][124] }\end{array}$ \\
\hline Al-30Zn & HPT for 5 turns at RT & 0.38 & T-CSR & 0.29 & $10^{-4}-10^{-3}$ & $\begin{array}{l}\text { Valiev et al. (2010) } \\
\text { [125] }\end{array}$ \\
\hline $\mathrm{Al}-30 \mathrm{Zn}$ & HPT for 5 turns at RT & 0.38 & M-CSR & 0.22 & $\begin{array}{l}6.25 \times 10^{-5}- \\
1.75 \times 10^{-2}\end{array}$ & $\begin{array}{l}\text { Chinh et al.(2012) } \\
\text { [126] }\end{array}$ \\
\hline Al-30Zn & $\mathrm{HPT}$ for 10 turns at RT & 0.35 & T-CSR & 0.26 & $10^{-4}-10^{-2}$ & $\begin{array}{l}\text { Bobruk et al. (2015) } \\
\text { [127] }\end{array}$ \\
\hline $\begin{array}{l}\text { Pure } \mathrm{Cu} \\
(99.98 \%)\end{array}$ & $\begin{array}{l}\text { ECAP (true logarithmic } \\
\text { strain of 4-7) at RT }\end{array}$ & 0.3 & T-CSR & 0.015 & $1 \times 10^{-3}-3 \times 10^{3}$ & $\begin{array}{l}\text { Gray III et al. } \\
\text { (1997)[128] }\end{array}$ \\
\hline $\begin{array}{l}\text { Pure Cu } \\
(99.996 \%)\end{array}$ & ECAP for $16 p$ at RT & 0.10 & T-SRJ & 0.14 & - & $\begin{array}{l}\text { Valiev et al. (2002) } \\
\text { [18] }\end{array}$ \\
\hline $\begin{array}{l}\text { Pure Cu } \\
(99.99 \%)\end{array}$ & ECAP for $8 p$ at RT & 0.3 & T-SRJ & $0.01-0.025$ & $6 \times 10^{-7}-1 \times 10^{-4}$ & $\begin{array}{l}\text { Wang \& Ma (2003) } \\
\text { [38] [129] }\end{array}$ \\
\hline $\begin{array}{l}\text { Pure Cu } \\
(99.99 \%)\end{array}$ & ECAP for $12 p$ at RT & 0.2 & C-SRJ & 0.02 & $10^{-4}-10^{-3}$ & $\begin{array}{l}\text { Li et al. (2004) } \\
{[130]}\end{array}$ \\
\hline Pure $\mathrm{Cu}$ & $\begin{array}{l}\text { ECAP for } 4 p \text { at } R T+\text { Cold } \\
\text { rolling }\end{array}$ & 0.2 & T-SRJ & 0.019 & $7 \times 10^{-6}-2 \times 10^{-4}$ & $\begin{array}{l}\text { Wei et al. (2004) } \\
\text { [62] }\end{array}$ \\
\hline $\begin{array}{l}\text { Pure } \mathrm{Cu} \\
(99.99 \%)\end{array}$ & $\mathrm{MC}^{* *}$ (strain of 7 ) at $\mathrm{RT}$ & $0.39 \pm 0.07$ & T-SRJ & $0.02-0.023$ & $10^{-6}-10^{-5}$ & $\begin{array}{l}\text { Li \& Blum (2005) } \\
\text { [131] }\end{array}$ \\
\hline $\begin{array}{l}\text { Pure } \mathrm{Cu} \\
(99.95 \%)\end{array}$ & ECAP up to $16 \mathrm{p}$ at RT & $0.2-0.3$ & C-SRJ & $0.02-0.024$ & $10^{-3}$ & $\begin{array}{l}\text { Dalla Torre et al. } \\
(2004)[132], \\
(2006)[133]\end{array}$ \\
\hline $\begin{array}{l}\text { Pure Cu } \\
(99.998 \%)\end{array}$ & ECAP for $8 p$ at RT & $0.19 \pm 0.08$ & N-CSR & $\begin{array}{l}0.020 \pm \\
0.007\end{array}$ & $10^{-5}-10^{-3 *}$ & $\begin{array}{l}\text { Chen et al. (2006) } \\
\text { [81] }\end{array}$ \\
\hline $\begin{array}{l}\text { Pure Cu } \\
(99.99 \%)\end{array}$ & $\begin{array}{l}\text { ECAP for } 12 p \text { at RT }+ \\
\text { Cryodrawing + Cryorolling }\end{array}$ & 0.23 & T-CSR & 0.018 & $1.7 \times 10^{-4}$ & $\begin{array}{l}\text { Zhao et al. (2006) } \\
\text { [134] }\end{array}$ \\
\hline Pure $\mathrm{Cu}$ & ECAP for $8 p$ at RT & $0.2-0.5$ & C-CSR & 0.034 & $5 \times 10^{-3}-1 \times 10^{-2}$ & $\begin{array}{l}\text { Mishra et al. (2008) } \\
\text { [135] }\end{array}$ \\
\hline $\begin{array}{l}\text { Pure Cu } \\
\text { (99.99\%) }\end{array}$ & $\begin{array}{l}\text { ECAP for } 2 p \text { at RT } \\
\text { ECAP for } 16 p \text { at RT }\end{array}$ & $\begin{array}{l}0.35-1.0 \\
0.3\end{array}$ & T-SRJ & $\begin{array}{l}0.010 \\
0.014\end{array}$ & $2 \times 10^{-5}-1 \times 10^{-2}$ & $\begin{array}{l}\text { Zhao et al. (2009) } \\
\text { [136] }\end{array}$ \\
\hline $\begin{array}{l}\text { Pure } \mathrm{Cu} \\
(99.99 \%) \\
\mathrm{Cu}-0.41 \mathrm{Si} \\
\mathrm{Cu}-1.64 \mathrm{Si}\end{array}$ & $\begin{array}{l}\text { ARB for } 8 \text { cycles at RT } \\
\text { ARB for } 10 \text { cycles at RT } \\
\text { ARB for } 6 \text { cycles at RT }\end{array}$ & $\begin{array}{l}0.37 \\
0.32\end{array}$ & T-SRJ & $\begin{array}{l}0.018 \\
0.013 \\
0.011\end{array}$ & $8.3 \times 10^{-5}-8.3 \times 10^{-4}$ & $\begin{array}{l}\text { Kunimine } \text { et al. } \\
\text { (2011)[137] }\end{array}$ \\
\hline Pure Cr & $\mathrm{HPT}$ for 10 turns at RT & 0.3 & N-SRJ & 0.02 & $5 \times 10^{-3}-5 \times 10^{-2}$ & $\begin{array}{l}\text { Maier } \text { et al. (2015) } \\
\text { [138] }\end{array}$ \\
\hline $\begin{array}{l}\text { Pure Fe } \\
(99.5 \%)\end{array}$ & $\begin{array}{l}\text { ECAP for } 4 p \text { at } R T \\
\text { ECAP for } 4 p \text { at } R T+\text { Cold } \\
\text { rolling }\end{array}$ & 0.3 & C-CSR & $\begin{array}{l}0.021 \\
0.021\end{array}$ & $5 \times 10^{-4}-1 \times 10^{0}$ & $\begin{array}{l}\text { Wei et al. (2004) } \\
\text { [139] }\end{array}$ \\
\hline Pure Fe & $\begin{array}{l}\text { ECAP for } 4 p \text { at RT } \\
\text { ECAP for } 4 p \text { at RT + Cold } \\
\text { rolling }\end{array}$ & 0.3 & T-SRJ & $\begin{array}{l}0.009 \\
0.007\end{array}$ & $7 \times 10^{-6}-2 \times 10^{-4}$ & $\begin{array}{l}\text { Wei etal. (2004) } \\
\text { [62] }\end{array}$ \\
\hline $\begin{array}{l}\text { Pure Fe } \\
(99.98 \%)\end{array}$ & ECAP for $6 p$ at RT & $0.19-0.41$ & C-SRJ & 0.018 & $10^{-6}-10^{-3}$ & $\begin{array}{l}\text { Höppel et al. (2005) } \\
\text { [23] }\end{array}$ \\
\hline $\begin{array}{l}\mathrm{Mg}-2.7 \mathrm{Zn}- \\
0.75 \mathrm{Zr}-0.45 \mathrm{Ag}- \\
0.17 \mathrm{Ca}-0.07 \mathrm{Mn}\end{array}$ & ECAP for $8 p$ at $498 K$ & $0.38 \pm 0.05$ & $\begin{array}{l}\text { T-SRJ } \\
\text { C-SRJ }\end{array}$ & $\begin{array}{l}0.02 \\
0.002\end{array}$ & $10^{-4}-10^{-2}$ & $\begin{array}{l}\text { Dalla Torre et al. } \\
\text { (2008)[140] }\end{array}$ \\
\hline
\end{tabular}




\begin{tabular}{|c|c|c|c|c|c|c|}
\hline \multirow[t]{2}{*}{ ZK60 } & \multirow[t]{2}{*}{ HPT for 2 turns at RT } & \multirow{2}{*}{$\begin{array}{l}1.0-1.5+20 \\
\text { (bimodal) }\end{array}$} & $\mathrm{N}-\mathrm{CSR}$ & $0.035-0.045$ & $1.25 \times 10^{-4}-1.0 \times 10^{3} *$ & \multirow{2}{*}{$\begin{array}{l}\text { Choi et al. (2015) } \\
\text { [85] }\end{array}$} \\
\hline & & & N-SRJ & $0.035-0.050$ & $2.5 \times 10^{-5}-2.5 \times 10^{-3} *$ & \\
\hline \multirow{2}{*}{$\begin{array}{l}\text { Pure Nb } \\
(99.9 \%)\end{array}$} & \multirow[t]{2}{*}{ ECAP for $16 p$ at RT } & \multirow[t]{2}{*}{-} & N-SRJ & 0.016 & $2.7 \times 10^{-3}$ & \multirow{2}{*}{$\begin{array}{l}\text { Alkorta et al. (2008) } \\
\text { [82] }\end{array}$} \\
\hline & & & $\mathrm{N}-\mathrm{Cr}$ & $0.011-0.014$ & $2.7 \times 10^{-5}$ & \\
\hline $\begin{array}{l}\text { Pure Ni } \\
(99.99 \%)\end{array}$ & $\begin{array}{l}\text { ECAP (true logarithmic } \\
\text { strain of 4-7) at RT }\end{array}$ & $\sim 0.3$ & T-CSR & 0.006 & $1 \times 10^{-3}-3 \times 10^{3}$ & $\begin{array}{l}\text { Gray III et al. } \\
\text { (1997)[128] }\end{array}$ \\
\hline $\begin{array}{l}\text { Pure Ni } \\
(99.98 \%)\end{array}$ & HPT for 5 turns at RT & $0.10 \pm 0.07$ & T-SRJ & $0.015-0.034$ & $2 \times 10^{-4}-2 \times 10^{-3}$ & $\begin{array}{l}\text { Dalla Torre et al. } \\
(2005)[141]\end{array}$ \\
\hline $\begin{array}{l}\text { Pure Ta } \\
(99.98 \%)\end{array}$ & ECAP for $4 p$ at RT & 0.2 & C-CSR & 0.025 & $10^{-3}-10^{3}$ & $\begin{array}{l}\text { Wei et al. (2003) } \\
{[142]}\end{array}$ \\
\hline Pure Ta & $\begin{array}{l}\text { ECAP for } 4 p \text { at RT + Cold } \\
\text { rolling }\end{array}$ & $\sim 0.25$ & T-SRJ & 0.007 & $7 \times 10^{-6}-2 \times 10^{-4}$ & $\begin{array}{l}\text { Wei et al. (2004) } \\
\text { [62] }\end{array}$ \\
\hline $\begin{array}{l}\text { Pure Ti } \\
(99.5 \%)\end{array}$ & $\begin{array}{l}\text { HPT (true logarithmic strain } \\
\text { of } 7 \text { ) at RT }\end{array}$ & 0.12 & T-SRJ & $0.12-0.15$ & - & $\begin{array}{l}\text { Valiev et al. (2003) } \\
\text { [28] }\end{array}$ \\
\hline Pure Ti & ECAP-conform & 0.1 & C-CSR & 0.1 & $10^{-4}-10^{-3}$ & $\begin{array}{l}\text { Lopes et al. (2015) } \\
\text { [143] }\end{array}$ \\
\hline Pure W & $\begin{array}{l}\text { ECAP ( true strain of } 3 \text { ) at } \\
1273-1373 \mathrm{~K}\end{array}$ & 0.5 & C-CSR & 0.025 & $10^{-4}-10^{3}$ & $\begin{array}{l}\text { Wei et al. (2005) } \\
{[144]}\end{array}$ \\
\hline Pure W & ECAP for $4 p$ at $1273 K$ & 0.5 & C-CSR & 0.026 & $10^{-4}-10^{3}$ & $\begin{array}{l}\text { Wei et al. (2006) } \\
{[145]}\end{array}$ \\
\hline \multirow[t]{3}{*}{ Pure W } & ECAP for $2 p$ at $873 \mathrm{~K}$ & 0.4 & \multirow[t]{3}{*}{$\mathrm{T}$-SRJ } & 0.023 & $10^{-4}$ & \multirow{3}{*}{$\begin{array}{l}\text { Pan et al. (2008) } \\
\text { [146] }\end{array}$} \\
\hline & ECAP for $2 p$ at $1073 \mathrm{~K}$ & 0.8 & & 0.028 & & \\
\hline & ECAP for $4 p$ at $1073 \mathrm{~K}$ & 0.3 & & 0.255 & & \\
\hline \multirow[t]{2}{*}{$\mathrm{Pb}-62 \mathrm{Sn}$} & HPT for 1 turn at RT & 1.5 & \multirow[t]{2}{*}{ N-CSR } & $0.37-0.45$ & $10^{-4}-10^{2}$ & \multirow{2}{*}{$\begin{array}{l}\text { Zhang et al. (2016) } \\
\text { [56] }\end{array}$} \\
\hline & $\begin{array}{l}\text { HPT for } 1 \text { turn at RT }+ \\
\text { Natural aging (20days) }\end{array}$ & 2.4 & & $0.30-0.45$ & & \\
\hline Zn-5Al & ECAP for $8 p$ at RT & $0.11-0.54$ & T-CSR & 0.25 & $10^{-4}-10^{-2}$ & $\begin{array}{l}\text { Demirtas et al. } \\
\text { (2015)[147] }\end{array}$ \\
\hline $\mathrm{Zn}-22 \mathrm{Al}$ & ECAP for $4 p$ at RT & 0.35 & T-CSR & $0.25-0.3$ & $10^{-4}-10^{-2}$ & $\begin{array}{l}\text { Tanaka and Higashi } \\
(2004)[148], \\
\text { Tanaka et al. }(2004) \\
{[149]}\end{array}$ \\
\hline $\mathrm{Zn}-22 \mathrm{Al}$ & ECAP for $8 p$ at RT & 0.55 & T-CSR & 0.35 & $10^{-2}-10^{-1}$ & $\begin{array}{l}\text { Xia et al. (2008) } \\
{[150]}\end{array}$ \\
\hline $\mathrm{Zn}-22 \mathrm{Al}$ & $\begin{array}{l}\text { ECAP for } 4 p \text { at } 623 K+4 p \\
\text { at RT }\end{array}$ & $0.15-0.21$ & T-CSR & 0.3 & $3 \times 10^{-2}-2 \times 10^{-1}$ & $\begin{array}{l}\text { Demirtas et al. } \\
\text { (2014) [89] }\end{array}$ \\
\hline $\mathrm{Zn}-22 \mathrm{Al}$ & HPT for 5 turns at RT & 0.35 & N-CSR & $0.226-0.256$ & $2.5 \times 10^{-4}-10^{-3} *$ & $\begin{array}{l}\text { Choi et al. (2014) } \\
\text { [66] }\end{array}$ \\
\hline $\begin{array}{l}\mathrm{Co}_{20} \mathrm{Cr}_{20} \mathrm{Fe}_{20} \\
\mathrm{Mn}_{20} \mathrm{Ni}_{20} \\
\text { (HEA) }\end{array}$ & HPT for 2 turns at RT & 0.04 & N-CSR & $\sim 0.03$ & $2.5 \times 10^{-4}-10^{-3} *$ & $\begin{array}{l}\text { Lee et al. (2015) } \\
{[67]}\end{array}$ \\
\hline Al-Mg MMNC & $\mathrm{HPT}$ for 5 turns at RT & 0.19 & $\mathrm{~N}-\mathrm{CSR}$ & $<0.01$ & $2.5 \times 10^{-4}-10^{-3} *$ & $\begin{array}{l}\text { Ahn etal. (2016) } \\
\text { [104] }\end{array}$ \\
\hline
\end{tabular}

* Nanoindentation strain rate was calculated to equivalent strain rate by applying the empirical relationship [65].

**MC: Multi compression 